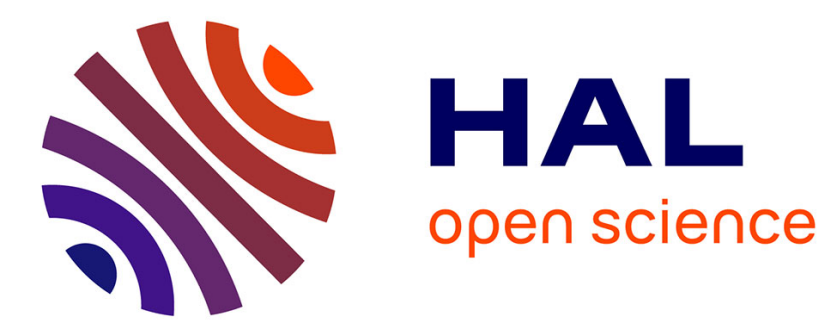

\title{
Ghrelin in Obesity and Endocrine Diseases
}

\author{
Miski Scerif, Anthony P Goldstone, Márta Korbonits
}

\section{To cite this version:}

Miski Scerif, Anthony P Goldstone, Márta Korbonits. Ghrelin in Obesity and Endocrine Diseases. Molecular and Cellular Endocrinology, 2011, 340 (1), pp.15. 10.1016/j.mce.2011.02.011 . hal00706320

\section{HAL Id: hal-00706320 https://hal.science/hal-00706320}

Submitted on 10 Jun 2012

HAL is a multi-disciplinary open access archive for the deposit and dissemination of scientific research documents, whether they are published or not. The documents may come from teaching and research institutions in France or abroad, or from public or private research centers.
L'archive ouverte pluridisciplinaire HAL, est destinée au dépôt et à la diffusion de documents scientifiques de niveau recherche, publiés ou non, émanant des établissements d'enseignement et de recherche français ou étrangers, des laboratoires publics ou privés. 


\section{Accepted Manuscript}

Title: Ghrelin in Obesity and Endocrine Diseases

Authors: Miski Scerif, Anthony P Goldstone, Márta Korbonits

PII:

DOI:

S0303-7207(11)00119-5

Reference: $\quad$ MCE 7774

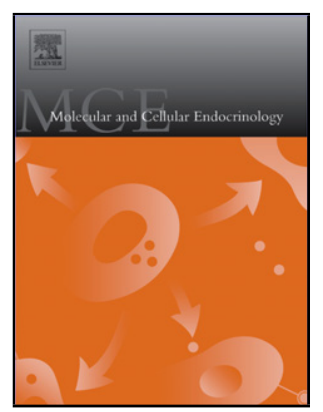

To appear in: $\quad$ Molecular and Cellular Endocrinology

Received date: $\quad$ 13-2-2011

Accepted date: $\quad$ 14-2-2011

Please cite this article as: Scerif, M., Goldstone, A.P., Korbonits, M., Ghrelin in Obesity and Endocrine Diseases, Molecular and Cellular Endocrinology (2010), doi:10.1016/j.mce.2011.02.011

This is a PDF file of an unedited manuscript that has been accepted for publication. As a service to our customers we are providing this early version of the manuscript. The manuscript will undergo copyediting, typesetting, and review of the resulting proof before it is published in its final form. Please note that during the production process errors may be discovered which could affect the content, and all legal disclaimers that apply to the journal pertain. 


\title{
Ghrelin in Obesity and Endocrine Diseases
}

\author{
Miski Scerif ${ }^{1}$, Anthony P Goldstone ${ }^{2}$ and Márta Korbonits ${ }^{1}$ \\ ${ }^{1}$ Centre for Endocrinology, William Harvey Research Institute, Barts and the London \\ School of Medicine and Dentistry, Queen Mary University of London, London EC1M \\ $6 B Q, U K$ \\ ${ }^{2}$ Metabolic and Molecular Imaging Group, MRC Clinical Sciences Centre, Imperial \\ College London, Hammersmith Hospital, London W12 ONN, UK
}

\section{Corresponding author}

Márta Korbonits MD, PhD

Professor of Endocrinology and Metabolism

Centre for Endocrinology, William Harvey Research Institute,

Barts and the London School of Medicine and Dentistry,

Queen Mary University of London,

Charterhouse Square,

London EC1M 6BQ

Tel: +442078826238

Fax: +44 2078826197

Email: $\underline{\text { m.korbonits@qmul.ac.uk }}$ 


\section{Ghrelin in Obesity}

\subsubsection{Appetite regulation}

The hypothalamus is crucial for appetite regulation and energy homeostasis. Afferent signals from peripheral sites such as the gastrointestinal tract and adipose tissues are integrated by complex neuronal networks to produce efferent responses responsible for food intake and energy metabolism (Druce \& Bloom, 2006). There are numerous hypothalamic appetite regulators. Orexigenic (appetite-stimulating) compounds include: neuropeptide Y (NPY), agouti-related peptide (AgRP), ghrelin, orexin and cannabinoids, and anorexigenic (appetite-suppressing) peptides include: pro-opiomelanocortin (POMC) and cocaine and amphetamine regulatory transcript (CART), thyrotropin-releasing hormone (TRH) and corticotropin-releasing hormone (CRH).

\subsubsection{Ghrelin and appetite regulation}

The appetite-stimulating function of ghrelin was identified secondary to its effect on growth hormone $(\mathrm{GH})$ release from somatotroph cells of the anterior pituitary (Korbonits \& Grossman, 2004), however, ghrelin is the first known peripheral hormone to display orexigenic effects through its action on the hypothalamic appetite-regulating pathways (Nakazato et al., 2001). In addition, ghrelin is amongst the most powerful of the orexigenic peptides (Kojima \& Kangawa, 2005). While most orexigenic peptides originate from the brain and are only active when injected into the brain, ghrelin is active even with peripheral administration leading to an increase in appetite in rodents and humans (Wren et al., 2001a; Wren et al., 2001b). Ghrelin activates NPY/AgRP neurons (Seoane et al., 2003) of the hypothalamic arcuate nucleus (ARC) through its receptor, 
GHS-R1a, promoting production and secretion of their orexigenic neuropeptides to suppress pro-POMC neuronal activity while promoting food intake (Cowley et al., 2003; Egecioglu et al., 2008). Interplay between ghrelin and orexin (Toshinai et al., 2003) suggests that arousal and wakefulness may be required for ghrelin's orexigenic effect (Olszewski et al., 2008). Mice with double knockout (KO) of NPY/AgRP genes completely lack the orexigenic action of ghrelin, confirming that these neuropeptides mediate and are essential for the orexigenic effect of this peptide hormone (Chen et al., 2004).

\subsection{AMPK and the orexigenic signaling pathway of ghrelin}

Adenosine monophosphate-activated protein kinase (AMPK) is an evolutionally well conserved heterotrimeric serine/threonine kinase composed of a catalytic $\alpha$ (alpha) subunit and regulatory $\beta$ (beta) and $\gamma$ (gamma) subunits. AMPK is a regulator of cellular and systemic energy homeostasis and acts as a sensor of energy status (Kola et al., 2006; Xiao et al., 2007). Once activated, AMPK leads to a switch from anabolic to catabolic pathways; with the aim of restoring energy balance, ATP production is increased and ATP-utilising pathways are inhibited. Hypothalamic AMPK plays a vital role in the regulation of food intake (Kola et al., 2006; Lim et al., 2010). Constitutively active AMPK increases both food intake and body weight; whereas dominant negative AMPK expression in the hypothalamus is sufficient to reduce food intake and body weight (Minokoshi et al., 2004).

The peripheral hormones ghrelin (Andersson et al., 2004; Kola et al., 2005) and adiponectin (Kadowaki et al., 2008; Kubota et al., 2007; Wen et al., 2010) both have 
hypothalamic AMPK implicated in their orexigenic effects. Hypothalamic AMPK has also been suggested as the mediator of the orexigenic effects of several other metabolic hormones and neuropeptides/modulators including cannabinoids (Kola et al., 2005) and glucocorticoids (Christ-Crain et al., 2008). Evidence that AMPK activity in the hypothalamus is also regulated by anorexigenic hormones: leptin (Andersson et al., 2004; Minokoshi et al., 2004) and insulin (Minokoshi et al., 2004), further demonstrates that hypothalamic AMPK is directly involved in appetite regulation.

We have shown that rat and mouse hypothalamic AMPK activity is stimulated by both central (intracerebroventricular) and peripheral (intraperitoneal) ghrelin administration (Kola et al., 2005; Kola et al., 2008). The central orexigenic effect of ghrelin is AMPK-dependent as compound C, an inhibitor of AMPK, completely prevented ghrelin's orexigenic effect, and adenoviruses harbouring $\alpha 1 / \alpha 2$ dominant negative AMPK were able to impair the stimulatory effect of ghrelin on food intake (Lopez et al., 2008). The signalling pathway of ghrelin's orexigenic effect in the hypothalamus has been further elucidated with the identification of the endocannabinoid system (Kola et al., 2005; Kola et al., 2008) and calmodulin kinase kinase 2 (CaMKK2) (Anderson et al., 2008) as upstream regulators to AMPK activation. The fatty acid pathways (Lopez et al., 2008) and mitochondrial uncoupling protein 2 (UCP2) (Andrews et al., 2008), have been identified as novel downstream effectors. Combining the recently described data, a pathway by which ghrelin could stimulate appetite has been suggested (Kola \& Korbonits, 2009) (Figure 1).

\subsection{Ghrelin in short- and long-term regulation of energy homeostasis}


There is evidence to show that ghrelin is important in short-term regulation of appetite and energy balance. The clear pre-prandial rise and post-prandial fall in plasma ghrelin levels support the hypothesis that ghrelin acts as an initiator signal for meal consumption in humans (Cummings et al., 2001). The pre-prandial increase of ghrelin levels was found to initiate meal consumption voluntarily, without time- or food-related cues (Cummings et al., 2004), whilst the post-prandial ghrelin suppression is proportional to the ingested calorie load (Callahan et al., 2004). Ghrelin also appears to be involved in the regulation of long-term energy homeostasis (Cummings, 2006). This peptide hormone has been described as the peripheral counterpart of insulin and leptin, and AMPK also appears to be involved in its peripheral metabolic effects (Kola et al., 2005) (Figure 2).

Ghrelin is able to reverse the down-regulating effect of insulin on mRNA levels of phosphoenolpyruvate carboxykinase (PEPCK), the rate limiting enzyme of gluconeogenesis (Murata et al., 2002). Ghrelin reduces glucose-stimulated insulin secretion and glucose disappearance in healthy humans (Tong et al., 2010) thus ghrelin leads to increase in blood glucose levels and impairs glucose tolerance (Korbonits \& Grossman, 2004). Ghrelin has been shown to significantly increase sterol-regulatory element binding protein-1 (SREBP1) mRNA levels, as well as several fat storage-related proteins, including acetyl-CoA carboxylase (ACC), fatty acid synthase (FAS) and lipoprotein lipase (LPL) leading to stimulation of intracytoplasmic lipid accumulation (Rodriguez et al., 2009). Ghrelin reduces the use of fat as a metabolic fuel and promotes an increase in adipose tissue and body weight (Tschop et al., 2000). Circulating ghrelin induces abdominal obesity, independently of its central orexigenic activity, via GHS-Rdependent lipid retention (Davies et al., 2009; Salome et al., 2009). 


\subsubsection{Obesity}

Obesity is a condition that results from chronic disruption of energy balance; energy intake continuously exceeds energy expenditure and accumulation of body fat follows (Hill, 2006). The prevalence of obesity is on the rise and the obesity pandemic is arguably amongst the most serious public health challenges in the world today. Obesity is strongly associated with type 2 diabetes mellitus, hyperlipidemia and cardiovascular disease, and provides significant contributions to ill health in both western and developing countries (Kopelman, 2000). Extensive research into the mechanisms of appetite regulation and energy balance has unveiled complex physiological systems behind energy homeostasis, and yielded potential targets for therapeutic intervention in the fight against obesity.

\subsubsection{Ghrelin and obesity}

Plasma ghrelin levels inversely correlate with body mass index (BMI). Thus, ghrelin levels are reduced in those who are obese compared to normal body weight controls (Tschop et al., 2001; Williams et al., 2006). Recent evidence suggests that dietinduced obesity causes ghrelin resistance by reducing NPY/AgRP responsiveness to plasma ghrelin and suppressing the neuroendocrine ghrelin axis, in an attempt to limit further food intake (Briggs et al., 2010). Ghrelin levels have been shown to negatively correlate with factors which are raised in obesity namely, percentage body fat, insulin and leptin levels (Tschop et al., 2001). In one study ghrelin levels were not related to fat mass or intra-abdominal fat content, but showed strong negative correlation with insulin levels 
and insulin resistance (Purnell et al., 2003). However in an MRI study of non-obese and obese adults, ghrelin was negatively correlated with visceral adiposity, fasting insulin, and homeostasis model insulin resistance index, with visceral adiposity having a stronger inverse correlation with ghrelin than subcutaneous fat depots possibly through hyperinsulinemia, as the negative correlations with insulin resistance were even stronger (Goldstone et al., 2004). Abnormal glucose homeostasis inversely correlated with, and was found to be an independent determinant of, plasma ghrelin levels in obese children and adolescents (Zhu et al., 2010).

It has been shown that selective ghrelin blockade, in diet-induced obese mice, results in reduction of food intake, bodyweight and body fat mass (Shearman et al., 2006). Adult ghrelin-deficient mice, compared to their wild-type littermates, display significantly lower glucose levels and increased insulin sensitivity under conditions of caloric restriction (Sun et al., 2008) and are protected from the rapid weight gain induced by early exposure to a high-fat diet (Wortley et al., 2005). In addition, mice lacking ghrelin receptors resist the development of diet-induced obesity (Zigman et al., 2005), and antagonism of the ghrelin receptor results in reduction of food intake and weight gain (Asakawa et al., 2003). Therefore, reduced levels of ghrelin activity in obese individuals, as compared with non-obese controls, should provide greater protection from further weight gain. However, obese individuals display smaller post-prandial reductions in serum ghrelin levels, perhaps leading to a reduced feeling of satiety (Goldstone et al., 2005; le Roux et al., 2005). In an earlier study, food intake failed to suppress ghrelin levels in obese humans (English et al., 2002). In addition, weight loss is associated with a 
simultaneous increase in plasma ghrelin levels (Cummings et al., 2002a; Hansen et al., 2002), which may make the maintenance of weight loss more difficult.

Obesity endangers the lives of millions of people worldwide, thus novel approaches to control body weight remain a high priority. Both ghrelin and GHS-R are being investigated as therapeutic targets (Schellekens et al., 2010). In vitro generated biostable RNA-based compounds that specifically bind ghrelin have been used in animal models to inhibit ghrelin-mediated GHS-R activation (Helmling et al., 2004). Zorilla et al. have developed an anti-ghrelin vaccine, providing a novel method to block ghrelin action (Zorrilla et al., 2006). Exciting prospects lie ahead for an anti-ghrelin vaccine to treat obesity (Carlson \& Cummings, 2006).

Ghrelin is acylated on its serine 3 residue with octanoate, an eight-carbon fatty acid. This post-translational modification is mediated by ghrelin O-acyltransferase (GOAT) (Yang et al., 2008) and is essential for GHS-R1a activation and the endocrine actions of ghrelin (Kojima \& Kangawa, 2005). Consistent with its function, GOAT mRNA is primarily limited to the stomach; the main ghrelin-secreting tissue (Yang et al., 2008). Acylated ghrelin induces body weight gain and adiposity by promoting food intake and decreasing energy expenditure (Asakawa et al., 2005; Tschop et al., 2000). GOAT has been implicated as another potential target for the development of anti-obesity treatment (Gualillo et al., 2008; Yang et al., 2008). Chronic treatment of mice on a high fat diet with GO-CoA-Tat, a peptide-based GOAT inhibitor, prevented the significant weight gain observed in vehicle-treated controls. Moreover, quantitative magnetic resonance (QMR) measurements showed that, relative to controls, GO-CoA-Tat treated animals displayed significantly lower fat mass, but not lean mass (Barnett et al., 2010). 


\subsection{Ghrelin and Prader-Willi syndrome}

Prader-Willi syndrome (PWS) is a complex genetic disorder characterised by childhood-onset hyperphagia-associated obesity, mental retardation, GH deficiency (short stature), hypogonadism, sleep and thermoregulation disturbance (Goldstone, 2004). The PWS genotype is characterized by loss of several paternal genes in the region q11-13 on chromosome 15 (Nicholls \& Knepper, 2001). PWS is a human genetic obesity syndrome and the most common cause of syndromic obesity.

In contrast to other forms of obesity, patients with PWS display significantly reduced visceral adiposity, and are protected from the metabolic complications of obesity, namely insulin resistance and hypertriglyceridemia (Goldstone et al., 2001). Patients with PWS have high ghrelin levels relative to their obesity, with fasting plasma concentrations up to three- to four-fold higher in PWS than in non-PWS obese controls. (Bizzarri et al., 2010; Cummings et al., 2002b; Gimenez-Palop et al., 2007; Goldstone et al., 2005; Haqq et al., 2003a; Paik et al., 2004). Levels of fasting ghrelin may also even be higher in PWS patients than in lean controls (Bizzarri et al., 2010; Choe et al., 2005a; Cummings et al., 2002b; Delparigi et al., 2002; Gimenez-Palop et al., 2007). Postprandial levels of ghrelin do fall in patients with PWS though they remain elevated compared to non-PWS obese controls, with conflicting results as to whether the magnitude of the decrease in ghrelin is blunted (Gimenez-Palop et al., 2007; Goldstone et al., 2005; Haqq et al., 2003b). In addition, the age-related decline in ghrelin is blunted in PWS infants and children (Haqq et al., 2008). 
Hypothalamic dysfunction has been suggested to underlie the obesity that is typical of PWS however fasting and post-prandial ghrelin levels are not elevated in patients with hypothalamic obesity (Goldstone et al., 2005; Kanumakala et al., 2005). Two- to three-fold increases in the numbers of ghrelin-expressing cells were noted in the gastric body and fundus of PWS patients as compared to lean and obese controls (Choe et al., 2005a). Imprinting of paternal genes in region q11-13 on chromosome 15 may induce the production of excessive amounts of transcription factors that increase ghrelin expression or, loss of a transcription inhibitory factor that normally suppresses ghrelin expression (Kojima \& Kangawa, 2005). Hyperghrelinemia of PWS appears to be partially, but not solely, explained by reduced visceral adiposity (Goldstone et al., 2004) and relative hypoinsulinemia (Goldstone et al., 2004; Goldstone et al., 2005). Other possible causes of the elevated ghrelin levels in PWS include abnormal parasympathetic vagal innervation of the stomach (Goldstone, 2004; Higgins et al., 2007) and abnormal sympathetic tone (Higgins et al., 2007).

Some studies have shown elevated ghrelin levels in PWS infants and children and thus it appears that hyperghrelinemia may precede hyperphagia in PWS, though this has not been universally seen in all studies (Erdie-Lalena et al., 2006; Feigerlova et al., 2008; Haqq et al., 2008). Neonatal transgenic deletion PWS mice die from severe neonatal hypoglycemia due to depletion of liver glycogen stores, and ghrelin levels increase reciprocally with the falling glucose levels (Stefan et al., 2005)

Although it has been hypothesised that hyperphagia in PWS may be partly explained by rapid gastric emptying due to increased gastric motility caused by elevated ghrelin levels, in fact patients with PWS have delayed gastric emptying (Choe et al., 
2005b). High circulating levels of ghrelin can be hypothesised as a potential cause for hyperphagia and obesity in PWS (Cummings et al., 2002b; Delparigi et al., 2002; Haqq et al., 2003a). However, not all PWS patients have elevated ghrelin levels, and pharmacological reduction of ghrelin levels to within normal levels using a somatostatin infusion was unable to reduce acute food intake in PWS adults (Tan et al., 2004). Futhermore, chronic treatment with a long-acting somatostatin analogue led to a sustained decrease in ghrelin concentrations but did not affect weight, eating behaviour or appetite in adolescents with PWS (De et al., 2008). However such interventions may also lower circulating anorexigenic gastroenteropancreatic hormones which may complicate their interpretation (De et al., 2008; Tan et al., 2004). Thus although other pathological defects are felt to cause or contribute to hyperphagia in PWS, including reduced circulating anorexigenic pancreatic polypeptide levels (Zipf et al., 1983), hypothalamic dysfunction (Goldstone et al., 2003; Goldstone, 2004), defects in brain reward and satiety systems (Hinton et al., 2006; Holsen et al., 2006; Miller et al., 2007), and decreased brain-derived neurotrophic factor (BDNF) which functions downstream of leptin and POMC/MC4R signalling (Han et al., 2010), it will need the clinical development of ghrelin antagonists or GOAT inhibitors to be able to definitively assess the role of hyperghrelinemia in the hyperphagia of PWS.

\subsubsection{Common genetic variations of $G H R L$ and $G H S-R$ genes in human obesity}

Relationships have been described between obesity and genomic variants of the ghrelin (GHRL) (Gueorguiev et al., 2009; Korbonits et al., 2002; Kuzuya et al., 2006; Leskela et al., 2009; Miraglia Del et al., 2004; Ukkola et al., 2001; Ukkola et al., 2002) 
and ghrelin receptor (GHS-R) (Baessler et al., 2005; Gueorguiev et al., 2009; Liu et al., 2007) genes.

The Leu72Met (C247A) polymorphism of the ghrelin gene was detected in $15.6 \%$ (12.5\% heterozygote and $3.1 \%$ homozygote) of obese subjects and in $12.5 \%$ (all heterozygotes) of non-obese control subjects. This polymorphism has been associated with an earlier onset of obesity (Ukkola et al., 2001). We studied the ghrelin gene in obese French children and found a positive correlation between the Leu72Met heterozygote variant with higher BMI and early-onset obesity (Korbonits et al., 2002) and a similar significant association between the Leu72Met polymorphism and earlyonset obesity was observed in Italian children (Miraglia Del et al., 2004). In addition, the Leu72Met polymorphism has been suggested to contribute to weight gain in middle-aged Japanese men (Kuzuya et al., 2006). However, the above findings could not be reproduced by other studies (Bing et al., 2005; Hinney et al., 2002; Jo et al., 2005; Zhu et al., 2010). Furthermore, one study of 3004 subjects even reported the Leu72Met polymorphism to be protective against fat accumulation; the polymorphism was related to lower BMI, fat mass and reduced visceral fat (Ukkola et al., 2002). Another study suggests that Leu72 allele carriers are more prone to weight variability in response to environmental factors given the reduced frequency of Leu72Met polymorphism in monozygotic twins discordant for obesity (Leskela et al., 2009).

The Arg51Gln (G185A) variant of the ghrelin gene was found in six (all heterozygotes) obese subjects $(6.3 \%)$ but was not found in non-obese controls (Ukkola et al., 2001). Obese subjects with the Arg51Gln variant had lower body weights than obese subjects with the wild-type Arg51Arg variant (Ukkola et al., 2001). Although studies 
have showed correlation between Arg51Gln and lower ghrelin levels (Poykko et al., 2003; Ukkola et al., 2002), another study was unable to confirm this finding (Vivenza et al., 2004).

Direct sequencing identified 12 GHRL single-nucleotide polymorphisms (SNPs) and 8 GHS-R SNPs (Gueorguiev et al., 2009). The GHRL polymorphism A265T and the $G H S-R$ polmorphism G477A have been associated with obesity in a French cohort of 263 families, while the $G H R L$ variant Leu72Met (C247A) and $G H S-R$ variant C60T may modulate eating patterns. However, after correction for multiple comparisons and testing in a German cohort with early-onset extreme obesity, it appears that these variants of $G H R L$ and $G H S-R$ genes are not strong genetic factors determining the susceptibility to obesity (Gueorguiev et al., 2009).

Linkage and association of SNPs and haplotypes within the $G H S-R$ gene region and human obesity has been demonstrated. Baessler et al. performed analysis of the entire $G H S-R$ gene region $(99.3 \mathrm{~kb})$ in 178 pedigrees with multiple obese members (1,095 Caucasian individuals) and in an independent sample of the general population (1,418 Caucasians individuals). The linkage disequilibrium analysis revealed a disequilibrium block consisting of five SNPs, which showed significant association with obesity in both study cohorts (Baessler et al., 2005). However, Wang et al. studied SNPs of the $G H S-R$ in German children and adolescents and failed to find conclusive evidence for the involvement of the GHS-R gene in body weight regulation (Wang et al., 2004). This is supported by a systematic study of common $G H S-R$ variants in three large population-based UK cohort studies comprising 5807 adults and 843 children, which found no association with body weight or BMI (Garcia et al., 2008). In addition, a 
population-based study of 15,854 Danish subjects, in which seven common GHS-R SNPs were genotyped, failed to show association between the $G H S-R$ variants and obesity (Gjesing et al., 2010). Further clinical studies are required to better define the frequency and the aetiological role of $G H S-R$ isoforms in obesity (Liu et al., 2007).

\subsection{2. $G H S-R$ mutations in patients}

Ala204Glu (Pantel et al., 2006; Wang et al., 2004) and Phe279Leu (Wang et al., 2004) are rare $G H S-R$ mutations which lead to loss of constitutive activity of GHS-R and subsequent short stature and obesity (Holst \& Schwartz, 2006). Obesity would be unexpected in loss-of-function mutations of GHS-R, however compensatory changes in related pathways may account for the obese phenotype in subjects with the inactivating mutations (Holst \& Schwartz, 2006). Four missense mutations of the GHS-R: Ala204Glu, Phe279Leu, Ile134Thr and Val160Met, have been reported and Liu et al. have shown that all these mutations affect the constitutive activity of the GHS-R, thus may have physiological consequences and/or pharmacogenomic implications (Liu et al., 2007).

Wang et al. studied 746 obese German children and adolescents, 232 underweight students, 96 normal-weight students and 43 children with short stature, and identified two individuals with novel missense mutations of the $G H S-R$. The Ala204Glu mutation was detected in a child with obesity and the Phe279Leu mutation was found in a child with short stature (Wang et al., 2004). Pantel et al. studied 2 unrelated families of Moroccan origin and identified a GHS-R missense mutation that segregates with short stature. The Ala204Glu mutation was not observed in a control group of Moroccan individuals with normal stature, indicating that it is not a frequent polymorphism. In family 1 , the 13 year 
old female proband with significant height reduction (3.7SD below the mean, according to French reference values) was found to carry the Ala204Glu mutation in the homozygous state; whilst the parents were heterozygous for this mutation (maternal and paternal height was noted to be $2.7 \mathrm{SD}$ and $3.7 \mathrm{SD}$ below the mean, respectively). In addition, several members of family 1 were overweight or obese - BMI of the 13 year old proband was $26.2 \mathrm{~kg} / \mathrm{m}^{2}$ (Pantel et al., 2006). In family 2, the 11 year old female proband was found to carry the same mutation in the heterozygous state, and the affected father (height 2SD below mean) was also heterozygous for the mutation (Pantel et al., 2006).

In contrast to the Ala204Glu mutation which has been implicated in short stature with dominant transmission; recessive GHS-R mutations have also been reported (Pantel et al., 2009). The proband was born to unrelated parents of normal phenotype, presented with episodes of abdominal pain, vomiting, hypoglycemia, and ketosis and required glucose infusions. He showed reduced height, weight, BMI and delayed bone age. Endocrine investigations revealed markedly low insulin-like growth factor 1 (IGF-1) levels and the patient displayed a low growth hormone $(\mathrm{GH})$ response to provocative tests. $G H S-R$ sequencing revealed that the patient was compound heterozygous for two new defects: a mutation predicting a premature stop codon $(\operatorname{Trp} 2 \mathrm{X})$ inherited from his unaffected father, therefore strongly arguing against haploinsufficiency as a disease mechanism, and a missense mutation (Arg237Trp), inherited from his healthy mother (Pantel et al., 2009).

In a study of 82 Danish obese probands and 28 lean subjects, a rare mutation in the promoter region $(-151 \mathrm{C} / \mathrm{T})$ of $G H S-R$ was identified in one obese individual. The $151 \mathrm{C} / \mathrm{T}$ mutation results in increased $G H S-R$ transcriptional activity thereby increased 
expression of GHS-R and increased potential for constitutive activity. This mutation cosegregated with obesity in the pedigree of the identified proband. The proband, her son, and sister had all been overweight or obese since the onset of puberty and her mother since her early twenties. Screening for the $-151 \mathrm{C} / \mathrm{T} G H S-R$ mutation was also performed in 289 obese Czech children, and an additional heterozygous carrier of the $-151 \mathrm{C} / \mathrm{T}$ mutation was identified. Co-segregation was seen for all obese individuals in the Czech pedigree; however two members of this pedigree were carriers of this mutation but not obese, possibly due to incomplete penetrance. The $-151 \mathrm{C} / \mathrm{T}$ mutation was subsequently genotyped in a population-based study of 15,854 Danish subjects; however in this study no association was found between the $-151 \mathrm{C} / \mathrm{T}$ mutation and obesity (Gjesing et al., 2010).

\subsection{Ghrelin and bariatric surgery}

Gastric bypass operations, the most common and most effective form of bariatric surgery, provide patients with morbid obesity an option of long-term sustained weight loss (Buchwald \& Williams, 2004; Fobi, 2004). Data regarding the alteration of ghrelin levels following gastric bypass surgery are inconsistent (Higgins et al., 2007; Pournaras \& le Roux, 2009; Pournaras \& le Roux, 2010; Vincent \& le Roux, 2008).

Many studies have shown gastric bypass operations to be associated with significant reduction of ghrelin levels (Cummings et al., 2002a; Geloneze et al., 2003; Lin et al., 2004; Roth et al., 2009; Stylopoulos et al., 2005; Suzuki et al., 2005). In addition, the normal, meal-related fluctuation and the diurnal rhythm of ghrelin level was found to be absent after gastric bypass surgery (Cummings et al., 2002a). Ghrelin levels 
were significantly suppressed in diet-induced obese rats post-gastric bypass as compared with both sham-operated obese and lean control rats (Shin et al., 2010). GHS-R1a protein expression in the hypothalamus was found to be much lower in rats following gastric bypass as compared to sham-operated controls (Wang \& Liu, 2010).

The suppression of ghrelin levels following gastric bypass surgery may contribute to reduced hunger and the weight-reducing effect of the procedure. However, the mechanism for the decrease in plasma ghrelin levels following gastric bypass is not yet known. It may be explained by major loss of gastric mucosa, thus ghrelin-producing endocrine cells. Alternatively, direct contact between gastric mucosa with food may be important for the production and secretion of ghrelin (Beckman et al., 2010; Kojima \& Kangawa, 2005).

In contrast, ghrelin levels have been found to remain unchanged after gastric bypass surgery in several studies (Pournaras \& le Roux, 2010; Vincent \& le Roux, 2008). Increases in ghrelin levels post-gastric bypass have also been seen (Garcia-Fuentes et al., 2008; Holdstock et al., 2003; Perez-Romero et al., 2010; Ybarra et al., 2009); however this may be associated with active weight loss rather than the surgery itself (Faraj et al., 2003). Several explanations have been proposed for the conflicting findings regarding ghrelin levels following gastric bypass surgery including differences in pre-operative insulin resistance, surgical methods and post-operative vagal nerve dysfunction (Pournaras \& le Roux, 2010; Vincent \& le Roux, 2008).

Weight loss following gastric banding is independent of circulating plasma ghrelin, as an increase in fasting ghrelin is accompanied by a paradoxical decrease in hunger, but relies on changes in eating behaviour induced by gastric restriction (Schindler 
et al., 2004). In sleeve gastrectomy, the fundus of the stomach, the main location of ghrelin-producing cells, is excluded and studies have confirmed a decrease in fasting ghrelin levels after the procedure (Cohen et al., 2005; Langer et al., 2005; Wang \& Liu, 2009). In a recent review, Beckman et al. suggest that the stronger, better designed studies indicate greatly reduced ghrelin levels in the post-gastric bypass state as compared to the obese or lean state, or when weight loss is achieved through procedures other than gastric bypass or through lifestyle modification (Beckman et al., 2010).

\section{Ghrelin and endocrine diseases}

The role of ghrelin in growth hormone deficiency, acromegaly, diabetes mellitus as well as in gastrointestinal neuroendocrine tumours will be discussed elsewhere in this special issue, but we will summarise data on Cushing's syndrome, thyroid disease, pheochromocytoma and insulinoma.

\subsubsection{Ghrelin and hypothalamic-pituitary-adrenal axis}

Ghrelin shows stimulatory effects on the corticotropic system (Giordano et al., 2004). Systemic administration of ghrelin, or the synthetic hexarelin, has been shown to increase ACTH and cortisol levels in healthy subjects (Arvat et al., 2001; Korbonits et al., 1999a). A hypothalamic site of action of ghrelin on the hypothalamic-pituitaryadrenal (HPA) axis has been proposed, as transection of the hypophyseal stalk dramatically decreased cortisol responses to synthetic growth hormone secretagogue (GHS) treatment (Hickey et al., 1996). Furthermore these compounds fail to increase ACTH release from pituitary tissue in vitro (Shimon et al., 1998). There are data to 
suggest that ghrelin stimulates the HPA axis at a hypothalamic level, at least in part via arginine vasopressin (AVP) and CRH (Coiro et al., 2005; Korbonits et al., 1999a; Mozid et al., 2003). It has been shown that NPY can stimulate CRH and AVP release from the rat hypothalamus (Korbonits et al., 1999b), therefore the effect of ghrelin on CRH and AVP could occur through direct action on CRH and AVP neurons in the paraventricular nucleus, or may occur indirectly via NPY (Mozid et al., 2003). Ghrelin does not have direct stimulatory effects on adrenal hormone secretion (Andreis et al., 2003; Barreiro et al., 2002). It appears that a feedback loop may exist between ghrelin levels and the HPA axis. While ghrelin stimulates the HPA axis, hypercortisolemia is associated with reduced ghrelin levels (Otto et al., 2004).

\subsubsection{Ghrelin and Cushing's syndrome}

The complications of Cushing's syndrome include central obesity, impaired glucose tolerance, insulin resistance, dyslipidemia, hepatic steatosis and systemic arterial hypertension (Arnaldi et al., 2003a) and eventually the metabolic syndrome (Anagnostis et al., 2009; Arnaldi et al., 2003a). Ghrelin levels are decreased in patients with Cushing's syndrome (Libe et al., 2005; Otto et al., 2004). This may be explained by the associated hyperinsulinemia and insulin resistance (Goldstone et al., 2004; Goldstone et al., 2005; Poykko et al., 2003). In Cushing's syndrome, the decrease in plasma ghrelin concentration is not associated with ACTH levels. Both endogenous hypercortisolemia, in which ACTH levels are reduced, and Cushing's disease which results from elevated ACTH secretion, lead to reduced ghrelin levels (Otto et al., 2004). Ghrelin levels significantly increased after successful surgical treatment of Cushing's disease (Libe et 
al., 2005; Otto et al., 2004). These findings make it unlikely that ghrelin has a causative role in the unfavourable energy balance and characteristic body composition of Cushing's syndrome (Otto et al., 2004), but rather it appears that ghrelin levels in Cushing's syndrome are altered as a consequence of the metabolic disturbance.

The ghrelin-induced secretion of ACTH and cortisol is enhanced in Cushing's disease patients as compared to healthy controls (Correa-Silva et al., 2006; Leal-Cerro et al., 2002; Miljic et al., 2010). GHS-R overexpression has been demonstrated in pituitary and ectopic ACTH-secreting tumours and in other neuroendocrine tumours (Arnaldi et al., 2003b; Korbonits et al., 2001). In patients with an ACTH-secreting tumour, ghrelin may further stimulate ACTH levels, and subsequently cortisol levels, through direct action on tumoral GHS-R (Correa-Silva et al., 2006). Ghrelin has been shown to act directly on corticotrope tumour cells derived from patients with Cushing's disease and this supports the suggestion of a cellular basis for the exaggerated ACTH response to ghrelin in Cushing's disease (Martinez-Fuentes et al., 2006). In addition, ghrelin has been shown in vitro to stimulate ACTH secretion by human ACTH-secreting pituitary adenomas (Pecori et al., 2007). After one month of ketoconazole treatment and potent inhibition of steroidogenesis, patients with Cushing's disease showed significant reduction in cortisol responses to ghrelin (Correa-Silva et al., 2007).

\subsection{Ghrelin and thyroid disease}

Graves' disease patients have been reported to display increased appetite and food intake as compared to healthy subjects and this hyperphagia may be a response to the excessive energy expenditure which characterises hyperthyroidism. Interestingly, 
normalisation of appetite occurs after pharmacological therapy (Cugini et al., 1999). It appears that the hyperphagia of hyperthyroidism is not mediated by circulating ghrelin (Katergari et al., 2008). Circulating plasma ghrelin levels are reduced in hyperthyroidism as compared to the euthyroid state (Altinova et al., 2006a), exhibit a positive correlation with thyroid stimulating hormone (TSH) levels (Sawicka et al., 2010) and rise to normal levels with pharmacological therapy of hyperthyroidism (Braclik et al., 2008; GimenezPalop et al., 2005; Riis et al., 2003; Rojdmark et al., 2005; Theodoropoulou et al., 2009). Total ghrelin levels were found to be significantly lower in overt than in subclinical hyperthyroid patients, with a trend to a reduction also in acylated ghrelin levels (Tanda et al., 2009). Insulin resistance is increased in hyperthyroidism (Gimenez-Palop et al., 2005) and hyperinsulinaemia has been shown to suppress ghrelin levels (Saad et al., 2002) regardless of thyroid status (Riis et al., 2003).

In hyperthyroid rats increased ghrelin-immunoreactivity in gastric mucosa has been observed along with the decreased plasma ghrelin concentration and this suggests that thyroxine may inhibit ghrelin secretion (Dadan et al., 2008).

There are variable data on ghrelin in hypothyroidism. A rat model of hypothyroidism showed increased circulating ghrelin and gastric ghrelin mRNA levels (Caminos et al., 2002). Following thyroxine replacement in hypothyroid patients, serum ghrelin levels showed a significant reduction (Braclik et al., 2008; Gjedde et al., 2008). In contrast, other studies have found ghrelin levels in hypothyroid patients to be similar to those of healthy subjects and there was no significant change in ghrelin levels after medical treatment of hypothyroidism (Gimenez-Palop et al., 2005; Sadegholvad et al., 2007; Tanda et al., 2009). Anti-parietal cell antibodies and atrophic gastritis has been 
detected in patients with autoimmune thyroid disease (Centanni et al., 1999). Furthermore, patients with Hashimoto's thyroiditis have displayed reduced ghrelin levels as compared to euthyroid subjects, and those with high thyroid peroxidase antibody titres showed greater reduction in ghrelin levels (Altinova et al., 2006b). Thus, thyroid peroxidase antibodies may have a ghrelin lowering effect. In autoimmune thyroid disease there may be reduced production of ghrelin due to destructive antibody-mediated action on the gastric mucosa.

Ghrelin and GHS-R1a mRNA expression has been demonstrated in normal human thyroid by RT-PCR (Gnanapavan et al., 2002). Another study found expression of ghrelin in fetal but not in infant or adult thyroid (Volante et al., 2003), and ghrelin may operate as a regulator of thyroid cell differentiation during normal development. Ghrelin appears to be re-expressed in thyroid tumours (Volante et al., 2003) and ghrelin immunoreactivity has been demonstrated in medullary, follicular and papillary thyroid carcinomas (Raghay et al., 2006). Human medullary thyroid carcinoma surgical specimens showed higher ghrelin content than normal thyroid tissues (Kanamoto et al., 2001). However, ghrelin levels were reduced in thyroid tissue of patients with papillary thyroid carcinoma, as compared with normal thyroid tissue (Karaoglu et al., 2009). Ghrelin (Volante et al., 2003) and growth hormone secretagogues (Cassoni et al., 2000) have been shown to inhibit in vitro cell proliferation of thyroid carcinoma cell lines, and may have a role in regulating thyroid tumour growth. Thus, high levels of ghrelin in thyroid tumours may be a mechanism by which there is an attempt to prevent tumour expansion. 


\subsection{Pheochromocytoma}

Pheochromocytomas are rare catecholamine-secreting tumours that arise from chromaffin cells of the adrenal medulla. Ghrelin immunoreactivity has been demonstrated in the medulla of human adrenal glands and in human pheochromocytomas (Raghay et al., 2008). Ghrelin has been shown to inhibit basal dopamine release and may have an effect in reducing the catecholamine secretion of pheochromocytomas (Nanmoku et al., 2003). The expression of ghrelin mRNA was found to be significantly less in pheochromocytomas as compared to normal adrenal tissue (Ueberberg et al., 2008), thus reduced ghrelin levels may have a role in the increased catecholamine secretion of pheochromocytomas.

\subsection{Insulinoma}

The role of ghrelin in beta-cell function is discussed elsewhere is this special issue. Expression of ghrelin and GHS-R1a mRNA has been detected in human insulinomas (Ekeblad et al., 2007; Volante et al., 2002). Acylated ghrelin, via the GHSR1a, was found to stimulate insulin secretion in INS-1E rat insulinoma cells. Unacylated ghrelin also stimulated insulin secretion but independently of GHS-R1a (Gauna et al., 2006). In contrast, ghrelin has recently been shown to inhibit insulin secretion in MIN6 insulinoma cells partly via the AMPK-UCP pathway (Wang et al., 2010).

\section{Conclusions}

There is currently much research into the numerous physiological and pathophysiological roles of ghrelin. Ghrelin plays a crucial function in appetite 
regulation, as well as short- and long-term energy homeostasis. The current obesity pandemic is a serious public health challenge. Antagonism of ghrelin and its signalling pathway may in future have a powerful role to play in the management of obesity. Continued research into PWS, genetic variations of ghrelin and GHS-R genes and gastric bypass and other forms of bariatric surgery will provide further insight into the role of ghrelin in obesity. Most likely as a result of secondary insulin resistance, altered ghrelin levels have also been observed in Cushing's syndrome and thyroid disease.

\section{Conflict of interest}

The authors declare that there is no conflict of interest. 


\section{References}

Altinova, A.E., Toruner, F.B., Akturk, M., Elbeg, S., Yetkin, I., Cakir, N., Arslan, M. 2006a. Reduced serum acylated ghrelin levels in patients with hyperthyroidism. Horm. Res. 65, 295-299.

Altinova, A.E., Toruner, F., Karakoc, A., Yetkin, I., Ayvaz, G., Cakir, N., Arslan, M. 2006b. Serum Ghrelin Levels in patients with Hashimoto's thyroiditis. Thyroid 16, 1259-1264.

Anagnostis, P., Athyros, V.G., Tziomalos, K., Karagiannis, A., Mikhailidis, D.P. 2009. Clinical review: The pathogenetic role of cortisol in the metabolic syndrome: a hypothesis. J. Clin. Endocrinol. Metab 94, 2692-2701.

Anderson, K.A., Ribar, T.J., Lin, F., Noeldner, P.K., Green, M.F., Muehlbauer, M.J., Witters, L.A., Kemp, B.E., Means, A.R. 2008. Hypothalamic CaMKK2 contributes to the regulation of energy balance. Cell Metab 7, 377-388.

Andersson, U., Filipsson, K., Abbott, C.R., Woods, A., Smith, K., Bloom, S.R., Carling, D., Small, C.J. 2004. AMP-activated protein kinase plays a role in the control of food intake. J. Biol. Chem. 279, 12005-12008.

Andreis, P.G., Malendowicz, L.K., Trejter, M., Neri, G., Spinazzi, R., Rossi, G.P., Nussdorfer, G.G. 2003. Ghrelin and growth hormone secretagogue receptor are expressed in the rat adrenal cortex: Evidence that ghrelin stimulates the growth, but not the secretory activity of adrenal cells. FEBS Lett. 536, 173-179.

Andrews, Z.B., Liu, Z.W., Walllingford, N., Erion, D.M., Borok, E., Friedman, J.M., Tschop, M.H., Shanabrough, M., Cline, G., Shulman, G.I., Coppola, A., Gao, X.B., Horvath, T.L., Diano, S. 2008. UCP2 mediates ghrelin's action on NPY/AgRP neurons by lowering free radicals. Nature 454, 846-851.

Arnaldi, G., Angeli, A., Atkinson, A.B., Bertagna, X., Cavagnini, F., Chrousos, G.P., Fava, G.A., Findling, J.W., Gaillard, R.C., Grossman, A.B., Kola, B., Lacroix, A., Mancini, T., Mantero, F., Newell-Price, J., Nieman, L.K., Sonino, N., Vance, M.L., Giustina, A., Boscaro, M. 2003a. Diagnosis and complications of Cushing's syndrome: a consensus statement. J. Clin. Endocrinol. Metab 88, 5593-5602.

Arnaldi, G., Mancini, T., Kola, B., Appolloni, G., Freddi, S., Concettoni, C., Bearzi, I., Masini, A., Boscaro, M., Mantero, F. 2003b. Cyclical Cushing's syndrome in a patient with a bronchial neuroendocrine tumor (typical carcinoid) expressing ghrelin and growth hormone secretagogue receptors. J. Clin. Endocrinol Metab 88, 5834-5840.

Arvat, E., Maccario, M., Di, V.L., Broglio, F., Benso, A., Gottero, C., Papotti, M., Muccioli, G., Dieguez, C., Casanueva, F.F., Deghenghi, R., Camanni, F., Ghigo, E. 2001. Endocrine activities of ghrelin, a natural growth hormone secretagogue (GHS), in humans: comparison and interactions with hexarelin, a nonnatural peptidyl GHS, and GHreleasing hormone. J. Clin. Endocrinol Metab 86, 1169-1174. 
Asakawa, A., Inui, A., Kaga, T., Katsuura, G., Fujimiya, M., Fujino, M.A., Kasuga, M. 2003. Antagonism of ghrelin receptor reduces food intake and body weight gain in mice. Gut 52, 947-952.

Asakawa, A., Inui, A., Fujimiya, M., Sakamaki, R., Shinfuku, N., Ueta, Y., Meguid, M.M., Kasuga, M. 2005. Stomach regulates energy balance via acylated ghrelin and desacyl ghrelin. Gut 54, 18-24.

Baessler, A., Hasinoff, M.J., Fischer, M., Reinhard, W., Sonnenberg, G.E., Olivier, M., Erdmann, J., Schunkert, H., Doering, A., Jacob, H.J., Comuzzie, A.G., Kissebah, A.H., Kwitek, A.E. 2005. Genetic linkage and association of the growth hormone secretagogue receptor (ghrelin receptor) gene in human obesity. Diabetes 54, 259-267.

Barnett, B.P., Hwang, Y., Taylor, M.S., Kirchner, H., Pfluger, P.T., Bernard, V., Lin, Y.Y., Bowers, E.M., Mukherjee, C., Song, W.J., Longo, P.A., Leahy, D.J., Hussain, M.A., Tschop, M.H., Boeke, J.D., Cole, P.A. 2010. Glucose and weight control in mice with a designed ghrelin O-acyltransferase inhibitor. Science 330, 1689-1692.

Barreiro, M.L., Pinilla, L., Aguilar, E., Tena-Sempere, M. 2002. Expression and homologous regulation of GH secretagogue receptor mRNA in rat adrenal gland. Eur. J. Endocrinol $147,677-688$.

Beckman, L.M., Beckman, T.R., Earthman, C.P. 2010. Changes in gastrointestinal hormones and leptin after Roux-en-Y gastric bypass procedure: a review. J. Am. Diet. Assoc. 110, 571584.

Bing, C., Ambye, L., Fenger, M., Jorgensen, T., Borch-Johnsen, K., Madsbad, S., Urhammer, S.A. 2005. Large-scale studies of the Leu72Met polymorphism of the ghrelin gene in relation to the metabolic syndrome and associated quantitative traits. Diabet. Med. 22, 1157-1160.

Bizzarri, C., Rigamonti, A.E., Luce, A., Cappa, M., Cella, S.G., Berini, J., Sartorio, A., Muller, E.E., Salvatoni, A. 2010. Children with Prader-Willi syndrome exhibit more evident meal-induced responses in plasma ghrelin and peptide YY levels than obese and lean children. Eur. J. Endocrinol 162, 499-505.

Braclik, M., Marcisz, C., Giebel, S., Orzel, A. 2008. Serum leptin and ghrelin levels in premenopausal women with stable body mass index during treatment of thyroid dysfunction. Thyroid 18, 545-550.

Briggs, D.I., Enriori, P.J., Lemus, M.B., Cowley, M.A., Andrews, Z.B. 2010. Diet-induced obesity causes ghrelin resistance in arcuate NPY/AgRP neurons. Endocrinology 151, 4745-4755.

Buchwald, H., Williams, S.E. 2004. Bariatric surgery worldwide 2003. Obes. Surg. 14, 1157 1164.

Callahan, H.S., Cummings, D.E., Pepe, M.S., Breen, P.A., Matthys, C.C., Weigle, D.S. 2004. Postprandial suppression of plasma ghrelin level is proportional to ingested caloric load but does not predict intermeal interval in humans. J. Clin. Endocrinol Metab 89, 13191324. 
Caminos, J.E., Seoane, L.M., Tovar, S.A., Casanueva, F.F., Dieguez, C. 2002. Influence of thyroid status and growth hormone deficiency on ghrelin. Eur. J. Endocrinol 147, 159163.

Carlson, M.J., Cummings, D.E. 2006. Prospects for an anti-ghrelin vaccine to treat obesity. Mol. Interv. 6, 249-252.

Cassoni, P., Papotti, M., Catapano, F., Ghe, C., Deghenghi, R., Ghigo, E., Muccioli, G. 2000. Specific binding sites for synthetic growth hormone secretagogues in non-tumoral and neoplastic human thyroid tissue. J. Endocrinol 165, 139-146.

Centanni, M., Marignani, M., Gargano, L., Corleto, V.D., Casini, A., Delle, F.G., Andreoli, M., Annibale, B. 1999. Atrophic body gastritis in patients with autoimmune thyroid disease: an underdiagnosed association. Arch. Intern. Med. 159, 1726-1730.

Chen, H.Y., Trumbauer, M.E., Chen, A.S., Weingarth, D.T., Adams, J.R., Frazier, E.G., Shen, Z., Marsh, D.J., Feighner, S.D., Guan, X.M., Ye, Z., Nargund, R.P., Smith, R.G., Van der Ploeg, L.H., Howard, A.D., MacNeil, D.J., Qian, S. 2004. Orexigenic action of peripheral ghrelin is mediated by neuropeptide Y and agouti-related protein. Endocrinology 145, 2607-2612.

Choe, Y.H., Song, S.Y., Paik, K.H., Oh, Y.J., Chu, S.H., Yeo, S.H., Kwon, E.K., Kim, E.M., Rha, M.Y., Jin, D.K. 2005a. Increased density of ghrelin-expressing cells in the gastric fundus and body in Prader-Willi syndrome. J. Clin. Endocrinol Metab 90, 5441-5445.

Choe, Y.H., Jin, D.K., Kim, S.E., Song, S.Y., Paik, K.H., Park, H.Y., Oh, Y.J., Kim, A.H., Kim, J.S., Kim, C.W., Chu, S.H., Kwon, E.K., Lee, K.H. 2005b. Hyperghrelinemia does not accelerate gastric emptying in Prader-Willi syndrome patients. J. Clin. Endocrinol Metab 90, 3367-3370.

Christ-Crain, M., Kola, B., Lolli, F., Fekete, C., Seboek, D., Wittmann, G., Feltrin, D., Igreja, S.C., Ajodha, S., Harvey-White, J., Kunos, G., Muller, B., Pralong, F., Aubert, G., Arnaldi, G., Giacchetti, G., Boscaro, M., Grossman, A.B., Korbonits, M. 2008. AMPactivated protein kinase mediates glucocorticoid-induced metabolic changes: a novel mechanism in Cushing's syndrome. FASEB J. 22, 1672-1683.

Cohen, R., Uzzan, B., Bihan, H., Khochtali, I., Reach, G., Catheline, J.M. 2005. Ghrelin levels and sleeve gastrectomy in super-super-obesity. Obes. Surg. 15, 1501-1502.

Coiro, V., Saccani-Jotti, G., Minelli, R., Melani, A., Milli, B., Manfredi, G., Volpi, R., Chiodera, P. 2005. Adrenocorticotropin/cortisol and arginine-vasopressin secretory patterns in response to ghrelin in normal men. Neuroendocrinology 81, 103-106.

Correa-Silva, S.R., Nascif, S.O., Lengyel, A.M. 2006. Decreased GH secretion and enhanced ACTH and cortisol release after ghrelin administration in Cushing's disease: comparison with GH-releasing peptide-6 (GHRP-6) and GHRH. Pituitary. 9, 101-107.

Correa-Silva, S.R., Nascif, S.O., Silva, M.R., Molica, P., Lengyel, A.M. 2007. Effect of one month ketoconazole treatment on GH, cortisol and ACTH release after ghrelin, GHRP-6 and GHRH administration in patients with Cushing's disease. Arq Bras. Endocrinol Metabol. 51, 1110-1117. 
Cowley, M.A., Smith, R.G., Diano, S., Tschop, M., Pronchuk, N., Grove, K.L., Strasburger, C.J., Bidlingmaier, M., Esterman, M., Heiman, M.L., Garcia-Segura, L.M., Nillni, E.A., Mendez, P., Low, M.J., Sotonyi, P., Friedman, J.M., Liu, H., Pinto, S., Colmers, W.F., Cone, R.D., Horvath, T.L. 2003. The distribution and mechanism of action of ghrelin in the CNS demonstrates a novel hypothalamic circuit regulating energy homeostasis. Neuron 37, 649-661.

Cugini, P., Paggi, A., Cristina, G., Ceccotti, P., Pellegrino, A.M., Fontana, S., Di, M.A., Vacca, K., Di, S.G. 1999. Hunger sensation in Graves' disease before and after pharmacological therapy. Clin. Ter. 150, 115-119.

Cummings, D.E., Purnell, J.Q., Frayo, R.S., Schmidova, K., Wisse, B.E., Weigle, D.S. 2001. A preprandial rise in plasma ghrelin levels suggests a role in meal initiation in humans. Diabetes 50, 1714-1719.

Cummings, D.E., Weigle, D.S., Frayo, R.S., Breen, P.A., Ma, M.K., Dellinger, E.P., Purnell, J.Q. 2002a. Plasma ghrelin levels after diet-induced weight loss or gastric bypass surgery. N. Engl. J. Med. 346, 1623-1630.

Cummings, D.E., Clement, K., Purnell, J.Q., Vaisse, C., Foster, K.E., Frayo, R.S., Schwartz, M.W., Basdevant, A., Weigle, D.S. 2002b. Elevated plasma ghrelin levels in Prader Willi syndrome. Nat. Med. 8, 643-644.

Cummings, D.E., Frayo, R.S., Marmonier, C., Aubert, R., Chapelot, D. 2004. Plasma ghrelin levels and hunger scores in humans initiating meals voluntarily without time- and foodrelated cues. Am. J. Physiol Endocrinol Metab 287, E297-E304

Cummings, D.E. 2006. Ghrelin and the short- and long-term regulation of appetite and body weight. Physiol Behav. 89, 71-84.

Dadan, J., Zbucki, R.L., Sawicki, B., Winnicka, M.M. 2008. Estimation of gastric ghrelinpositive cells activity in hyperthyroid rats. Folia Histochem. Cytobiol. 46, 511-517.

Davies, J.S., Kotokorpi, P., Eccles, S.R., Barnes, S.K., Tokarczuk, P.F., Allen, S.K., Whitworth, H.S., Guschina, I.A., Evans, B.A., Mode, A., Zigman, J.M., Wells, T. 2009. Ghrelin induces abdominal obesity via GHS-R-dependent lipid retention. Mol. Endocrinol 23, 914-924.

De, W.K., Ishkanian, S.L., Bogarin, R., Miranda, C.A., Ghatei, M.A., Bloom, S.R., Pacaud, D., Chanoine, J.P. 2008. Long-acting octreotide treatment causes a sustained decrease in ghrelin concentrations but does not affect weight, behaviour and appetite in subjects with Prader-Willi syndrome. Eur. J. Endocrinol 159, 381-388.

Delparigi, A., Tschop, M., Heiman, M.L., Salbe, A.D., Vozarova, B., Sell, S.M., Bunt, J.C., Tataranni, P.A. 2002. High circulating ghrelin: a potential cause for hyperphagia and obesity in prader-willi syndrome. J. Clin. Endocrinol Metab 87, 5461-5464.

Druce, M., Bloom, S.R. 2006. The regulation of appetite. Arch. Dis. Child 91, 183-187. 
Egecioglu, E., Stenstrom, B., Pinnock, S.B., Tung, L.Y., Dornonville, d.1.C., Lindqvist, A., Hakanson, R., Syversen, U., Chen, D., Dickson, S.L. 2008. Hypothalamic gene expression following ghrelin therapy to gastrectomized rodents. Regul. Pept. 146, 176182.

Ekeblad, S., Lejonklou, M.H., Grimfjard, P., Johansson, T., Eriksson, B., Grimelius, L., Stridsberg, M., Stalberg, P., Skogseid, B. 2007. Co-expression of ghrelin and its receptor in pancreatic endocrine tumours. Clin. Endocrinol (Oxf) 66, 115-122.

English, P.J., Ghatei, M.A., Malik, I.A., Bloom, S.R., Wilding, J.P. 2002. Food fails to suppress ghrelin levels in obese humans. J. Clin. Endocrinol Metab 87, 2984

Erdie-Lalena, C.R., Holm, V.A., Kelly, P.C., Frayo, R.S., Cummings, D.E. 2006. Ghrelin levels in young children with Prader-Willi syndrome. J. Pediatr. 149, 199-204.

Faraj, M., Havel, P.J., Phelis, S., Blank, D., Sniderman, A.D., Cianflone, K. 2003. Plasma acylation-stimulating protein, adiponectin, leptin, and ghrelin before and after weight loss induced by gastric bypass surgery in morbidly obese subjects. J. Clin. Endocrinol Metab $88,1594-1602$.

Feigerlova, E., Diene, G., Conte-Auriol, F., Molinas, C., Gennero, I., Salles, J.P., Arnaud, C., Tauber, M. 2008. Hyperghrelinemia precedes obesity in Prader-Willi syndrome. J. Clin. Endocrinol Metab 93, 2800-2805.

Fobi, M.A. 2004. Surgical treatment of obesity: a review. J. Natl. Med. Assoc. 96, 61-75.

Garcia, E.A., Heude, B., Petry, C.J., Gueorguiev, M., Hassan-Smith, Z.K., Spanou, A., Ring, S.M., Dunger, D.B., Wareham, N., Sandhu, M.S., Ong, K.K., Korbonits, M. 2008. Ghrelin receptor gene polymorphisms and body size in children and adults. J. Clin. Endocrinol Metab 93, 4158-4161.

Garcia-Fuentes, E., Garrido-Sanchez, L., Garcia-Almeida, J.M., Garcia-Arnes, J., GallegoPerales, J.L., Rivas-Marin, J., Morcillo, S., Cardona, I., Soriguer, F. 2008. Different effect of laparoscopic Roux-en-Y gastric bypass and open biliopancreatic diversion of Scopinaro on serum PYY and ghrelin levels. Obes. Surg. 18, 1424-1429.

Gauna, C., Delhanty, P.J., van Aken, M.O., Janssen, J.A., Themmen, A.P., Hofland, L.J., Culler, M., Broglio, F., Ghigo, E., van der Lely, A.J. 2006. Unacylated ghrelin is active on the INS-1E rat insulinoma cell line independently of the growth hormone secretagogue receptor type 1a and the corticotropin releasing factor 2 receptor. Mol. Cell Endocrinol $251,103-111$.

Geloneze, B., Tambascia, M.A., Pilla, V.F., Geloneze, S.R., Repetto, E.M., Pareja, J.C. 2003. Ghrelin: a gut-brain hormone: effect of gastric bypass surgery. Obes. Surg. 13, 17-22.

Gimenez-Palop, O., Gimenez-Perez, G., Mauricio, D., Berlanga, E., Potau, N., Vilardell, C., Arroyo, J., Gonzalez-Clemente, J.M., Caixas, A. 2005. Circulating ghrelin in thyroid dysfunction is related to insulin resistance and not to hunger, food intake or anthropometric changes. Eur. J. Endocrinol 153, 73-79. 
Gimenez-Palop, O., Gimenez-Perez, G., Mauricio, D., Gonzalez-Clemente, J.M., Potau, N., Berlanga, E., Trallero, R., Laferrere, B., Caixas, A. 2007. A lesser postprandial suppression of plasma ghrelin in Prader-Willi syndrome is associated with low fasting and a blunted postprandial PYY response. Clin. Endocrinol (Oxf) 66, 198-204.

Giordano, R., Picu, A., Broglio, F., Bonelli, L., Baldi, M., Berardelli, R., Ghigo, E., Arvat, E. 2004. Ghrelin, hypothalamus-pituitary-adrenal (HPA) axis and Cushing's syndrome. Pituitary. 7, 243-248.

Gjedde, S., Vestergaard, E.T., Gormsen, L.C., Riis, A.L., Rungby, J., Moller, N., Weeke, J., Jorgensen, J.O. 2008. Serum ghrelin levels are increased in hypothyroid patients and become normalized by L-thyroxine treatment. J. Clin. Endocrinol Metab 93, 2277-2280.

Gjesing, A.P., Larsen, L.H., Torekov, S.S., Hainerova, I.A., Kapur, R., Johansen, A., Albrechtsen, A., Boj, S., Holst, B., Harper, A., Urhammer, S.A., Borch-Johnsen, K., Pisinger, C., Echwald, S.M., Eiberg, H., Astrup, A., Lebl, J., Ferrer, J., Schwartz, T.W., Hansen, T., Pedersen, O. 2010. Family and population-based studies of variation within the ghrelin receptor locus in relation to measures of obesity. PLoS. One. 5, e10084

Gnanapavan, S., Kola, B., Bustin, S.A., Morris, D.G., McGee, P., Fairclough, P., Bhattacharya, S., Carpenter, R., Grossman, A.B., Korbonits, M. 2002. The tissue distribution of the mRNA of ghrelin and subtypes of its receptor, GHS-R, in humans. J. Clin. Endocrinol Metab 87, 2988

Goldstone, A.P., Thomas, E.L., Brynes, A.E., Bell, J.D., Frost, G., Saeed, N., Hajnal, J.V., Howard, J.K., Holland, A., Bloom, S.R. 2001. Visceral adipose tissue and metabolic complications of obesity are reduced in Prader-Willi syndrome female adults: evidence for novel influences on body fat distribution. J. Clin. Endocrinol Metab 86, 4330-4338.

Goldstone, A.P., Unmehopa, U.A., Thomas, E.L., Brynes, A.E., Bell, J.D., Frost, G., Ghatei, M.A., Holland, A., Bloom, S.R., Swaab, D.F. 2003. Hypothalamic neuropeptides and regulation of fat mass in Prader-Willi syndrome. In: U Eiholzer, D l'Allemand, W Zipf (eds.) Prader-Willi Syndrome as a Model for Obesity. Basel, Switzerland: Karger Publishers, pp.31-43.

Goldstone, A.P. 2004. Prader-Willi syndrome: advances in genetics, pathophysiology and treatment. Trends Endocrinol Metab 15, 12-20.

Goldstone, A.P., Thomas, E.L., Brynes, A.E., Castroman, G., Edwards, R., Ghatei, M.A., Frost, G., Holland, A.J., Grossman, A.B., Korbonits, M., Bloom, S.R., Bell, J.D. 2004. Elevated fasting plasma ghrelin in prader-willi syndrome adults is not solely explained by their reduced visceral adiposity and insulin resistance. J. Clin. Endocrinol Metab 89, 17181726.

Goldstone, A.P., Patterson, M., Kalingag, N., Ghatei, M.A., Brynes, A.E., Bloom, S.R., Grossman, A.B., Korbonits, M. 2005. Fasting and postprandial hyperghrelinemia in Prader-Willi syndrome is partially explained by hypoinsulinemia, and is not due to peptide YY3-36 deficiency or seen in hypothalamic obesity due to craniopharyngioma. J. Clin. Endocrinol Metab 90, 2681-2690. 
Gualillo, O., Lago, F., Dieguez, C. 2008. Introducing GOAT: a target for obesity and antidiabetic drugs? Trends Pharmacol. Sci. 29, 398-401.

Gueorguiev, M., Lecoeur, C., Meyre, D., Benzinou, M., Mein, C.A., Hinney, A., Vatin, V., Weill, J., Heude, B., Hebebrand, J., Grossman, A.B., Korbonits, M., Froguel, P. 2009. Association studies on ghrelin and ghrelin receptor gene polymorphisms with obesity. Obesity. (Silver. Spring) 17, 745-754.

Han, J.C., Muehlbauer, M.J., Cui, H.N., Newgard, C.B., Haqq, A.M. 2010. Lower brain-derived neurotrophic factor in patients with prader-willi syndrome compared to obese and lean control subjects. J. Clin. Endocrinol Metab 95, 3532-3536.

Hansen, T.K., Dall, R., Hosoda, H., Kojima, M., Kangawa, K., Christiansen, J.S., Jorgensen, J.O. 2002. Weight loss increases circulating levels of ghrelin in human obesity. Clin. Endocrinol (Oxf) 56, 203-206.

Haqq, A.M., Farooqi, I.S., O'Rahilly, S., Stadler, D.D., Rosenfeld, R.G., Pratt, K.L., LaFranchi, S.H., Purnell, J.Q. 2003a. Serum ghrelin levels are inversely correlated with body mass index, age, and insulin concentrations in normal children and are markedly increased in Prader-Willi syndrome. J. Clin. Endocrinol Metab 88, 174-178.

Haqq, A.M., Stadler, D.D., Rosenfeld, R.G., Pratt, K.L., Weigle, D.S., Frayo, R.S., LaFranchi, S.H., Cummings, D.E., Purnell, J.Q. 2003b. Circulating ghrelin levels are suppressed by meals and octreotide therapy in children with Prader-Willi syndrome. J. Clin. Endocrinol Metab 88, 3573-3576.

Haqq, A.M., Grambow, S.C., Muehlbauer, M., Newgard, C.B., Svetkey, L.P., Carrel, A.L., Yanovski, J.A., Purnell, J.Q., Freemark, M. 2008. Ghrelin concentrations in Prader-Willi syndrome (PWS) infants and children: changes during development. Clin. Endocrinol (Oxf) 69, 911-920.

Helmling, S., Maasch, C., Eulberg, D., Buchner, K., Schroder, W., Lange, C., Vonhoff, S., Wlotzka, B., Tschop, M.H., Rosewicz, S., Klussmann, S. 2004. Inhibition of ghrelin action in vitro and in vivo by an RNA-Spiegelmer. Proc. Natl. Acad. Sci. U. S. A 101, 13174-13179.

Hickey, G.J., Drisko, J., Faidley, T., Chang, C., Anderson, L.L., Nicolich, S., McGuire, L., Rickes, E., Krupa, D., Feeney, W., Friscino, B., Cunningham, P., Frazier, E., Chen, H., Laroque, P., Smith, R.G. 1996. Mediation by the central nervous system is critical to the in vivo activity of the GH secretagogue L-692,585. J. Endocrinol 148, 371-380.

Higgins, S.C., Gueorguiev, M., Korbonits, M. 2007. Ghrelin, the peripheral hunger hormone. Ann. Med. 39, 116-136.

Hill, J.O. 2006. Understanding and addressing the epidemic of obesity: an energy balance perspective. Endocr. Rev. 27, 750-761.

Hinney, A., Hoch, A., Geller, F., Schafer, H., Siegfried, W., Goldschmidt, H., Remschmidt, H., Hebebrand, J. 2002. Ghrelin gene: identification of missense variants and a frameshift mutation in extremely obese children and adolescents and healthy normal weight students. J. Clin. Endocrinol Metab 87, 2716 
Hinton, E.C., Holland, A.J., Gellatly, M.S., Soni, S., Patterson, M., Ghatei, M.A., Owen, A.M. 2006. Neural representations of hunger and satiety in Prader-Willi syndrome. Int. J. Obes. (Lond) 30, 313-321.

Holdstock, C., Engstrom, B.E., Ohrvall, M., Lind, L., Sundbom, M., Karlsson, F.A. 2003. Ghrelin and adipose tissue regulatory peptides: effect of gastric bypass surgery in obese humans. J. Clin. Endocrinol Metab 88, 3177-3183.

Holsen, L.M., Zarcone, J.R., Brooks, W.M., Butler, M.G., Thompson, T.I., Ahluwalia, J.S., Nollen, N.L., Savage, C.R. 2006. Neural mechanisms underlying hyperphagia in PraderWilli syndrome. Obesity. (Silver. Spring) 14, 1028-1037.

Holst, B., Schwartz, T.W. 2006. Ghrelin receptor mutations--too little height and too much hunger. J. Clin. Invest 116, 637-641.

Jo, D.S., Kim, S.L., Kim, S.Y., Hwang, P.H., Lee, K.H., Lee, D.Y. 2005. Preproghrelin Leu72Met polymorphism in obese Korean children. J. Pediatr. Endocrinol Metab 18, 1083-1086.

Kadowaki, T., Yamauchi, T., Kubota, N. 2008. The physiological and pathophysiological role of adiponectin and adiponectin receptors in the peripheral tissues and CNS. FEBS Lett. 582, 74-80.

Kanamoto, N., Akamizu, T., Hosoda, H., Hataya, Y., Ariyasu, H., Takaya, K., Hosoda, K., Saijo, M., Moriyama, K., Shimatsu, A., Kojima, M., Kangawa, K., Nakao, K. 2001. Substantial production of ghrelin by a human medullary thyroid carcinoma cell line. J. Clin. Endocrinol Metab 86, 4984-4990.

Kanumakala, S., Greaves, R., Pedreira, C.C., Donath, S., Warne, G.L., Zacharin, M.R., Harris, M. 2005. Fasting ghrelin levels are not elevated in children with hypothalamic obesity. J. Clin. Endocrinol Metab 90, 2691-2695.

Karaoglu, A., Aydin, S., Dagli, A.F., Cummings, D.E., Ozercan, I.H., Canatan, H., Ozkan, Y. 2009. Expression of obestatin and ghrelin in papillary thyroid carcinoma. Mol. Cell Biochem. 323, 113-118.

Katergari, S.A., Milousis, A., Pagonopoulou, O., Asimakopoulos, B., Nikolettos, N.K. 2008. Ghrelin in pathological conditions. Endocr. J. 55, 439-453.

Kojima, M., Kangawa, K. 2005. Ghrelin: structure and function. Physiol Rev. 85, 495-522.

Kola, B., Hubina, E., Tucci, S.A., Kirkham, T.C., Garcia, E.A., Mitchell, S.E., Williams, L.M., Hawley, S.A., Hardie, D.G., Grossman, A.B., Korbonits, M. 2005. Cannabinoids and ghrelin have both central and peripheral metabolic and cardiac effects via AMP-activated protein kinase. J. Biol. Chem. 280, 25196-25201.

Kola, B., Boscaro, M., Rutter, G.A., Grossman, A.B., Korbonits, M. 2006. Expanding role of AMPK in endocrinology. Trends Endocrinol Metab 17, 205-215. 
Kola, B., Farkas, I., Christ-Crain, M., Wittmann, G., Lolli, F., Amin, F., Harvey-White, J., Liposits, Z., Kunos, G., Grossman, A.B., Fekete, C., Korbonits, M. 2008. The orexigenic effect of ghrelin is mediated through central activation of the endogenous cannabinoid system. PLoS. One. 3, e1797

Kola, B., Korbonits, M. 2009. Shedding light on the intricate puzzle of ghrelin's effects on appetite regulation. J. Endocrinol 202, 191-198.

Kopelman, P.G. 2000. Obesity as a medical problem. Nature 404, 635-643.

Korbonits, M., Kaltsas, G., Perry, L.A., Putignano, P., Grossman, A.B., Besser, G.M., Trainer, P.J. 1999a. The growth hormone secretagogue hexarelin stimulates the hypothalamopituitary-adrenal axis via arginine vasopressin. J. Clin. Endocrinol Metab 84, 2489-2495.

Korbonits, M., Little, J.A., Forsling, M.L., Tringali, G., Costa, A., Navarra, P., Trainer, P.J., Grossman, A.B. 1999b. The effect of growth hormone secretagogues and neuropeptide $Y$ on hypothalamic hormone release from acute rat hypothalamic explants. J. Neuroendocrinol. 11, 521-528.

Korbonits, M., Bustin, S.A., Kojima, M., Jordan, S., Adams, E.F., Lowe, D.G., Kangawa, K., Grossman, A.B. 2001. The expression of the growth hormone secretagogue receptor ligand ghrelin in normal and abnormal human pituitary and other neuroendocrine tumors. J. Clin. Endocrinol Metab 86, 881-887.

Korbonits, M., Gueorguiev, M., O'Grady, E., Lecoeur, C., Swan, D.C., Mein, C.A., Weill, J., Grossman, A.B., Froguel, P. 2002. A variation in the ghrelin gene increases weight and decreases insulin secretion in tall, obese children. J. Clin. Endocrinol Metab 87, 40054008 .

Korbonits, M., Grossman, A.B. 2004. Ghrelin: update on a novel hormonal system. Eur. J. Endocrinol 151 Suppl 1, S67-S70

Kubota, N., Yano, W., Kubota, T., Yamauchi, T., Itoh, S., Kumagai, H., Kozono, H., Takamoto, I., Okamoto, S., Shiuchi, T., Suzuki, R., Satoh, H., Tsuchida, A., Moroi, M., Sugi, K., Noda, T., Ebinuma, H., Ueta, Y., Kondo, T., Araki, E., Ezaki, O., Nagai, R., Tobe, K., Terauchi, Y., Ueki, K., Minokoshi, Y., Kadowaki, T. 2007. Adiponectin stimulates AMPactivated protein kinase in the hypothalamus and increases food intake. Cell Metab 6, 5568 .

Kuzuya, M., Ando, F., Iguchi, A., Shimokata, H. 2006. Preproghrelin Leu72Met variant contributes to overweight in middle-aged men of a Japanese large cohort. Int. J. Obes. (Lond) 30, 1609-1614.

Langer, F.B., Reza Hoda, M.A., Bohdjalian, A., Felberbauer, F.X., Zacherl, J., Wenzl, E., Schindler, K., Luger, A., Ludvik, B., Prager, G. 2005. Sleeve gastrectomy and gastric banding: effects on plasma ghrelin levels. Obes. Surg. 15, 1024-1029.

le Roux, C.W., Patterson, M., Vincent, R.P., Hunt, C., Ghatei, M.A., Bloom, S.R. 2005. Postprandial plasma ghrelin is suppressed proportional to meal calorie content in normalweight but not obese subjects. J. Clin. Endocrinol Metab 90, 1068-1071. 
Leal-Cerro, A., Torres, E., Soto, A., Dios, E., Deghenghi, R., Arvat, E., Ghigo, E., Dieguez, C., Casanueva, F.F. 2002. Ghrelin is no longer able to stimulate growth hormone secretion in patients with Cushing's syndrome but instead induces exaggerated corticotropin and cortisol responses. Neuroendocrinology 76, 390-396.

Leskela, P., Ukkola, O., Vartiainen, J., Ronnemaa, T., Kaprio, J., Bouchard, C., Kesaniemi, Y.A. 2009. Fasting plasma total ghrelin concentrations in monozygotic twins discordant for obesity. Metabolism 58, 174-179.

Libe, R., Morpurgo, P.S., Cappiello, V., Maffini, A., Bondioni, S., Locatelli, M., Zavanone, M., Beck-Peccoz, P., Spada, A. 2005. Ghrelin and adiponectin in patients with Cushing's disease before and after successful transsphenoidal surgery. Clin. Endocrinol (Oxf) 62, 30-36.

Lim, C.T., Kola, B., Korbonits, M. 2010. AMPK as a mediator of hormonal signalling. J. Mol. Endocrinol 44, 87-97.

Lin, E., Gletsu, N., Fugate, K., McClusky, D., Gu, L.H., Zhu, J.L., Ramshaw, B.J., Papanicolaou, D.A., Ziegler, T.R., Smith, C.D. 2004. The effects of gastric surgery on systemic ghrelin levels in the morbidly obese. Arch. Surg. 139, 780-784.

Liu, G., Fortin, J.P., Beinborn, M., Kopin, A.S. 2007. Four missense mutations in the ghrelin receptor result in distinct pharmacological abnormalities. J. Pharmacol. Exp. Ther. 322, 1036-1043.

Lopez, M., Lage, R., Saha, A.K., Perez-Tilve, D., Vazquez, M.J., Varela, L., Sangiao-Alvarellos, S., Tovar, S., Raghay, K., Rodriguez-Cuenca, S., Deoliveira, R.M., Castaneda, T., Datta, R., Dong, J.Z., Culler, M., Sleeman, M.W., Alvarez, C.V., Gallego, R., Lelliott, C.J., Carling, D., Tschop, M.H., Dieguez, C., Vidal-Puig, A. 2008. Hypothalamic fatty acid metabolism mediates the orexigenic action of ghrelin. Cell Metab 7, 389-399.

Martinez-Fuentes, A.J., Moreno-Fernandez, J., Vazquez-Martinez, R., Duran-Prado, M., de la Riva, A., Tena-Sempere, M., Dieguez, C., Jimenez-Reina, L., Webb, S.M., Pumar, A., Leal-Cerro, A., Benito-Lopez, P., Malagon, M.M., Castano, J.P. 2006. Ghrelin is produced by and directly activates corticotrope cells from adrenocorticotropin-secreting adenomas. J. Clin. Endocrinol Metab 91, 2225-2231.

Miljic, D., Joksimovic, M., Doknic, M., Ivovic, M., Djurovic, M., Pekic, S., Tancic, M., Soldatovic, I., Stojanovic, M., Nale, D., Macut, D., Damjanovic, S., Popovic, V. 2010. ACTH and cortisol responses to ghrelin and DDAVP in patients with Cushing's disease (CD) and adrenal enlargement. J. Endocrinol Invest 33, 526-529.

Miller, J.L., James, G.A., Goldstone, A.P., Couch, J.A., He, G., Driscoll, D.J., Liu, Y. 2007. Enhanced activation of reward mediating prefrontal regions in response to food stimuli in Prader-Willi syndrome. J. Neurol. Neurosurg. Psychiatry 78, 615-619.

Minokoshi, Y., Alquier, T., Furukawa, N., Kim, Y.B., Lee, A., Xue, B., Mu, J., Foufelle, F., Ferre, P., Birnbaum, M.J., Stuck, B.J., Kahn, B.B. 2004. AMP-kinase regulates food intake by responding to hormonal and nutrient signals in the hypothalamus. Nature 428, 569-574. 
Miraglia Del, G.E., Santoro, N., Cirillo, G., Raimondo, P., Grandone, A., D'Aniello, A., Di, N.M., Perrone, L. 2004. Molecular screening of the ghrelin gene in Italian obese children: the Leu72Met variant is associated with an earlier onset of obesity. Int. J. Obes. Relat Metab Disord. 28, 447-450.

Mozid, A.M., Tringali, G., Forsling, M.L., Hendricks, M.S., Ajodha, S., Edwards, R., Navarra, P., Grossman, A.B., Korbonits, M. 2003. Ghrelin is released from rat hypothalamic explants and stimulates corticotrophin-releasing hormone and arginine-vasopressin. Horm. Metab Res. 35, 455-459.

Murata, M., Okimura, Y., Iida, K., Matsumoto, M., Sowa, H., Kaji, H., Kojima, M., Kangawa, K., Chihara, K. 2002. Ghrelin modulates the downstream molecules of insulin signaling in hepatoma cells. J. Biol. Chem. 277, 5667-5674.

Nakazato, M., Murakami, N., Date, Y., Kojima, M., Matsuo, H., Kangawa, K., Matsukura, S. 2001. A role for ghrelin in the central regulation of feeding. Nature 409, 194-198.

Nanmoku, T., Takekoshi, K., Ishi, K., Kawakami, Y., Isobe, K., Shibuya, S., Okuda, Y., Nakai, T. 2003. Effect of Ghrelin on catecholamine secretion in rat pheochromocytoma PC12 cells. Endocr. Res. 29, 17-21.

Nicholls, R.D., Knepper, J.L. 2001. Genome organization, function, and imprinting in PraderWilli and Angelman syndromes. Annu. Rev. Genomics Hum. Genet. 2, 153-175.

Olszewski, P.K., Schioth, H.B., Levine, A.S. 2008. Ghrelin in the CNS: from hunger to a rewarding and memorable meal? Brain Res. Rev. 58, 160-170.

Otto, B., Tschop, M., Heldwein, W., Pfeiffer, A.F., Diederich, S. 2004. Endogenous and exogenous glucocorticoids decrease plasma ghrelin in humans. Eur. J. Endocrinol 151, 113-117.

Paik, K.H., Jin, D.K., Song, S.Y., Lee, J.E., Ko, S.H., Song, S.M., Kim, J.S., Oh, Y.J., Kim, S.W., Lee, S.H., Kim, S.H., Kwon, E.K., Choe, Y.H. 2004. Correlation between fasting plasma ghrelin levels and age, body mass index (BMI), BMI percentiles, and 24-hour plasma ghrelin profiles in Prader-Willi syndrome. J. Clin. Endocrinol Metab 89, 3885-3889.

Pantel, J., Legendre, M., Cabrol, S., Hilal, L., Hajaji, Y., Morisset, S., Nivot, S., Vie-Luton, M.P., Grouselle, D., de, K.M., Kadiri, A., Epelbaum, J., le, B.Y., Amselem, S. 2006. Loss of constitutive activity of the growth hormone secretagogue receptor in familial short stature. J. Clin. Invest 116, 760-768.

Pantel, J., Legendre, M., Nivot, S., Morisset, S., Vie-Luton, M.P., le, B.Y., Epelbaum, J., Amselem, S. 2009. Recessive isolated growth hormone deficiency and mutations in the ghrelin receptor. J. Clin. Endocrinol Metab 94, 4334-4341.

Pecori, G.F., Bucciarelli, L.G., Saccani, A., Scacchi, M., Pesce, S., Losa, M., Cavagnini, F. 2007. Ghrelin stimulates adrenocorticotrophic hormone (ACTH) secretion by human ACTHsecreting pituitary adenomas in vitro. J. Neuroendocrinol. 19, 208-212. 
Perez-Romero, N., Serra, A., Granada, M.L., Rull, M., Alastrue, A., Navarro-Diaz, M., Romero, R., Fernandez-Llamazares, J. 2010. Effects of two variants of Roux-en-Y Gastric bypass on metabolism behaviour: focus on plasma ghrelin concentrations over a 2-year followup. Obes. Surg. 20, 600-609.

Pournaras, D.J., le Roux, C.W. 2009. The effect of bariatric surgery on gut hormones that alter appetite. Diabetes Metab 35, 508-512.

Pournaras, D.J., le Roux, C.W. 2010. Ghrelin and metabolic surgery. Int. J. Pept. 2010, Article ID 217267, 1-5.

Poykko, S.M., Kellokoski, E., Horkko, S., Kauma, H., Kesaniemi, Y.A., Ukkola, O. 2003. Low plasma ghrelin is associated with insulin resistance, hypertension, and the prevalence of type 2 diabetes. Diabetes 52, 2546-2553.

Purnell, J.Q., Weigle, D.S., Breen, P., Cummings, D.E. 2003. Ghrelin levels correlate with insulin levels, insulin resistance, and high-density lipoprotein cholesterol, but not with gender, menopausal status, or cortisol levels in humans. J. Clin. Endocrinol Metab 88, 57475752.

Raghay, K., Garcia-Caballero, T., Nogueiras, R., Morel, G., Beiras, A., Dieguez, C., Gallego, R. 2006. Ghrelin localization in rat and human thyroid and parathyroid glands and tumours. Histochem. Cell Biol. 125, 239-246.

Raghay, K., Garcia-Caballero, T., Bravo, S., Alvarez, C.V., Gonzalez, R., Dieguez, C., Beiras, A., Fraga, M., Gallego, R. 2008. Ghrelin localization in the medulla of rat and human adrenal gland and in pheochromocytomas. Histol. Histopathol. 23, 57-65.

Riis, A.L., Hansen, T.K., Moller, N., Weeke, J., Jorgensen, J.O. 2003. Hyperthyroidism is associated with suppressed circulating ghrelin levels. J. Clin. Endocrinol Metab 88, 853857.

Rodriguez, A., Gomez-Ambrosi, J., Catalan, V., Gil, M.J., Becerril, S., Sainz, N., Silva, C., Salvador, J., Colina, I., Fruhbeck, G. 2009. Acylated and desacyl ghrelin stimulate lipid accumulation in human visceral adipocytes. Int. J. Obes. (Lond) 33, 541-552.

Rojdmark, S., Calissendorff, J., Danielsson, O., Brismar, K. 2005. Hunger-satiety signals in patients with Graves' thyrotoxicosis before, during, and after long-term pharmacological treatment. Endocrine. 27, 55-61.

Roth, C.L., Reinehr, T., Schernthaner, G.H., Kopp, H.P., Kriwanek, S., Schernthaner, G. 2009. Ghrelin and obestatin levels in severely obese women before and after weight loss after Roux-en-Y gastric bypass surgery. Obes. Surg. 19, 29-35.

Saad, M.F., Bernaba, B., Hwu, C.M., Jinagouda, S., Fahmi, S., Kogosov, E., Boyadjian, R. 2002. Insulin regulates plasma ghrelin concentration. J. Clin. Endocrinol Metab 87, 3997-4000.

Sadegholvad, A., Afkhamizadeh, M., Ranjbar-Omrani, G. 2007. Serum ghrelin changes in thyroid dysfunction. Arch. Iran Med. 10, 168-170. 
Salome, N., Hansson, C., Taube, M., Gustafsson-Ericson, L., Egecioglu, E., Karlsson-Lindahl, L., Fehrentz, J.A., Martinez, J., Perrissoud, D., Dickson, S.L. 2009. On the central mechanism underlying ghrelin's chronic pro-obesity effects in rats: new insights from studies exploiting a potent ghrelin receptor (GHS-R1A) antagonist. J. Neuroendocrinol. 21, 777-785.

Sawicka, B., Bossowski, A., Szalecki, M., Wysoka, J., Koput, A., Zelazowska-Rutkowska, B., Tobolczyk, J., Rogowski, F., Luba, M. 2010. Relationship between metabolic parameters and thyroid hormones and the level of gastric peptides in children with autoimmune thyroid diseases. J. Pediatr. Endocrinol Metab 23, 345-354.

Schellekens, H., Dinan, T.G., Cryan, J.F. 2010. Lean mean fat reducing "ghrelin" machine: hypothalamic ghrelin and ghrelin receptors as therapeutic targets in obesity. Neuropharmacology 58, 2-16.

Schindler, K., Prager, G., Ballaban, T., Kretschmer, S., Riener, R., Buranyi, B., Maier, C., Luger, A., Ludvik, B. 2004. Impact of laparoscopic adjustable gastric banding on plasma ghrelin, eating behaviour and body weight. Eur. J. Clin. Invest 34, 549-554.

Seoane, L.M., Lopez, M., Tovar, S., Casanueva, F.F., Senaris, R., Dieguez, C. 2003. Agoutirelated peptide, neuropeptide $\mathrm{Y}$, and somatostatin-producing neurons are targets for ghrelin actions in the rat hypothalamus. Endocrinology 144, 544-551.

Shearman, L.P., Wang, S.P., Helmling, S., Stribling, D.S., Mazur, P., Ge, L., Wang, L., Klussmann, S., Macintyre, D.E., Howard, A.D., Strack, A.M. 2006. Ghrelin neutralization by a ribonucleic acid-SPM ameliorates obesity in diet-induced obese mice. Endocrinology 147, 1517-1526.

Shimon, I., Yan, X., Melmed, S. 1998. Human fetal pituitary expresses functional growth hormone-releasing peptide receptors. J. Clin. Endocrinol Metab 83, 174-178.

Shin, A.C., Zheng, H., Townsend, R.L., Sigalet, D.L., Berthoud, H.R. 2010. Meal-induced hormone responses in a rat model of Roux-en-Y gastric bypass surgery. Endocrinology $151,1588-1597$.

Stefan, M., Ji, H., Simmons, R.A., Cummings, D.E., Ahima, R.S., Friedman, M.I., Nicholls, R.D. 2005. Hormonal and metabolic defects in a prader-willi syndrome mouse model with neonatal failure to thrive. Endocrinology 146, 4377-4385.

Stylopoulos, N., Davis, P., Pettit, J.D., Rattner, D.W., Kaplan, L.M. 2005. Changes in serum ghrelin predict weight loss after Roux-en-Y gastric bypass in rats. Surg. Endosc. 19, 942946.

Sun, Y., Butte, N.F., Garcia, J.M., Smith, R.G. 2008. Characterization of adult ghrelin and ghrelin receptor knockout mice under positive and negative energy balance. Endocrinology 149, 843-850.

Suzuki, S., Ramos, E.J., Goncalves, C.G., Chen, C., Meguid, M.M. 2005. Changes in GI hormones and their effect on gastric emptying and transit times after Roux-en-Y gastric bypass in rat model. Surgery 138, 283-290. 
Tan, T.M., Vanderpump, M., Khoo, B., Patterson, M., Ghatei, M.A., Goldstone, A.P. 2004. Somatostatin infusion lowers plasma ghrelin without reducing appetite in adults with Prader-Willi syndrome. J. Clin. Endocrinol Metab 89, 4162-4165.

Tanda, M.L., Lombardi, V., Genovesi, M., Ultimieri, F., Lai, A., Gandolfo, M., Dalle, M., I, Grasso, L., Bogazzi, F., Broglio, F., Ghigo, E., Martino, E., Bartalena, L. 2009. Plasma total and acylated Ghrelin concentrations in patients with clinical and subclinical thyroid dysfunction. J. Endocrinol Invest 32, 74-78.

Theodoropoulou, A., Psyrogiannis, A., Metallinos, I.C., Habeos, I., Vgenakis, A.G., Kyriazopoulou, V. 2009. Ghrelin response to oral glucose load in hyperthyroidism, before and after treatment with antithyroid drugs. J. Endocrinol Invest 32, 94-97.

Tong, J., Prigeon, R.L., Davis, H.W., Bidlingmaier, M., Kahn, S.E., Cummings, D.E., Tschop, M.H., D'Alessio, D. 2010. Ghrelin suppresses glucose-stimulated insulin secretion and deteriorates glucose tolerance in healthy humans. Diabetes 59, 2145-2151.

Toshinai, K., Date, Y., Murakami, N., Shimada, M., Mondal, M.S., Shimbara, T., Guan, J.L., Wang, Q.P., Funahashi, H., Sakurai, T., Shioda, S., Matsukura, S., Kangawa, K., Nakazato, M. 2003. Ghrelin-induced food intake is mediated via the orexin pathway. Endocrinology 144, 1506-1512.

Tschop, M., Smiley, D.L., Heiman, M.L. 2000. Ghrelin induces adiposity in rodents. Nature 407, 908-913.

Tschop, M., Weyer, C., Tataranni, P.A., Devanarayan, V., Ravussin, E., Heiman, M.L. 2001. Circulating ghrelin levels are decreased in human obesity. Diabetes 50, 707-709.

Ueberberg, B., Unger, N., Sheu, S.Y., Walz, M.K., Schmid, K.W., Saeger, W., Mann, K., Petersenn, S. 2008. Differential expression of ghrelin and its receptor (GHS-R1a) in various adrenal tumors and normal adrenal gland. Horm. Metab Res. 40, 181-188.

Ukkola, O., Ravussin, E., Jacobson, P., Snyder, E.E., Chagnon, M., Sjostrom, L., Bouchard, C. 2001. Mutations in the preproghrelin/ghrelin gene associated with obesity in humans. J. Clin. Endocrinol Metab 86, 3996-3999.

Ukkola, O., Ravussin, E., Jacobson, P., Perusse, L., Rankinen, T., Tschop, M., Heiman, M.L., Leon, A.S., Rao, D.C., Skinner, J.S., Wilmore, J.H., Sjostrom, L., Bouchard, C. 2002. Role of ghrelin polymorphisms in obesity based on three different studies. Obes. Res. 10, 782-791.

Vincent, R.P., le Roux, C.W. 2008. Changes in gut hormones after bariatric surgery. Clin. Endocrinol (Oxf) 69, 173-179.

Vivenza, D., Rapa, A., Castellino, N., Bellone, S., Petri, A., Vacca, G., Aimaretti, G., Broglio, F., Bona, G. 2004. Ghrelin gene polymorphisms and ghrelin, insulin, IGF-I, leptin and anthropometric data in children and adolescents. Eur. J. Endocrinol 151, 127-133. 
Volante, M., Allia, E., Gugliotta, P., Funaro, A., Broglio, F., Deghenghi, R., Muccioli, G., Ghigo, E., Papotti, M. 2002. Expression of ghrelin and of the GH secretagogue receptor by pancreatic islet cells and related endocrine tumors. J. Clin. Endocrinol Metab 87, 13001308.

Volante, M., Allia, E., Fulcheri, E., Cassoni, P., Ghigo, E., Muccioli, G., Papotti, M. 2003. Ghrelin in fetal thyroid and follicular tumors and cell lines: expression and effects on tumor growth. Am. J. Pathol. 162, 645-654.

Wang, H.J., Geller, F., Dempfle, A., Schauble, N., Friedel, S., Lichtner, P., Fontenla-Horro, F., Wudy, S., Hagemann, S., Gortner, L., Huse, K., Remschmidt, H., Bettecken, T., Meitinger, T., Schafer, H., Hebebrand, J., Hinney, A. 2004. Ghrelin receptor gene: identification of several sequence variants in extremely obese children and adolescents, healthy normal-weight and underweight students, and children with short normal stature. J. Clin. Endocrinol Metab 89, 157-162.

Wang, Y., Liu, J. 2009. Plasma ghrelin modulation in gastric band operation and sleeve gastrectomy. Obes. Surg. 19, 357-362.

Wang, Y., Liu, J. 2010. Combination of bypassing stomach and vagus dissection in high-fat dietinduced obese rats-a long-term investigation. Obes. Surg. 20, 375-379.

Wang, Y., Nishi, M., Doi, A., Shono, T., Furukawa, Y., Shimada, T., Furuta, H., Sasaki, H., Nanjo, K. 2010. Ghrelin inhibits insulin secretion through the AMPK-UCP2 pathway in beta cells. FEBS Lett. 584, 1503-1508.

Wen, J.P., Liu, C.E., Hu, Y.T., Chen, G., Lin, L.X. 2010. Globular adiponectin regulates energy homeostasis through AMP-activated protein kinase-acetyl-CoA carboxylase (AMPK/ACC) pathway in the hypothalamus. Mol. Cell Biochem. 344, 109-115.

Williams, D.L., Grill, H.J., Cummings, D.E., Kaplan, J.M. 2006. Overfeeding-induced weight gain suppresses plasma ghrelin levels in rats. J. Endocrinol Invest 29, 863-868.

Wortley, K.E., del Rincon, J.P., Murray, J.D., Garcia, K., Iida, K., Thorner, M.O., Sleeman, M.W. 2005. Absence of ghrelin protects against early-onset obesity. J. Clin. Invest 115, 3573-3578.

Wren, A.M., Seal, L.J., Cohen, M.A., Brynes, A.E., Frost, G.S., Murphy, K.G., Dhillo, W.S., Ghatei, M.A., Bloom, S.R. 2001a. Ghrelin enhances appetite and increases food intake in humans. J. Clin. Endocrinol Metab 86, 5992

Wren, A.M., Small, C.J., Abbott, C.R., Dhillo, W.S., Seal, L.J., Cohen, M.A., Batterham, R.L., Taheri, S., Stanley, S.A., Ghatei, M.A., Bloom, S.R. 2001b. Ghrelin causes hyperphagia and obesity in rats. Diabetes 50, 2540-2547.

Xiao, B., Heath, R., Saiu, P., Leiper, F.C., Leone, P., Jing, C., Walker, P.A., Haire, L., Eccleston, J.F., Davis, C.T., Martin, S.R., Carling, D., Gamblin, S.J. 2007. Structural basis for AMP binding to mammalian AMP-activated protein kinase. Nature 449, 496-500. 
Yang, J., Brown, M.S., Liang, G., Grishin, N.V., Goldstein, J.L. 2008. Identification of the acyltransferase that octanoylates ghrelin, an appetite-stimulating peptide hormone. Cell 132, 387-396.

Ybarra, J., Bobbioni-Harsch, E., Chassot, G., Huber, O., Morel, P., Assimacopoulos-Jeannet, F., Golay, A. 2009. Persistent correlation of ghrelin plasma levels with body mass index both in stable weight conditions and during gastric-bypass-induced weight loss. Obes. Surg. $19,327-331$.

Zhu, J.F., Liang, L., Zou, C.C., Fu, J.F. 2010. Plasma ghrelin levels and polymorphisms of ghrelin gene in Chinese obese children and adolescents. Ir. J. Med. Sci. 179, 345-349.

Zigman, J.M., Nakano, Y., Coppari, R., Balthasar, N., Marcus, J.N., Lee, C.E., Jones, J.E., Deysher, A.E., Waxman, A.R., White, R.D., Williams, T.D., Lachey, J.L., Seeley, R.J., Lowell, B.B., Elmquist, J.K. 2005. Mice lacking ghrelin receptors resist the development of diet-induced obesity. J. Clin. Invest 115, 3564-3572.

Zipf, W.B., O'Dorisio, T.M., Cataland, S., Dixon, K. 1983. Pancreatic polypeptide responses to protein meal challenges in obese but otherwise normal children and obese children with Prader-Willi syndrome. J. Clin. Endocrinol Metab 57, 1074-1080.

Zorrilla, E.P., Iwasaki, S., Moss, J.A., Chang, J., Otsuji, J., Inoue, K., Meijler, M.M., Janda, K.D. 2006. Vaccination against weight gain. Proc. Natl. Acad. Sci. U. S. A 103, 13226-13231. 


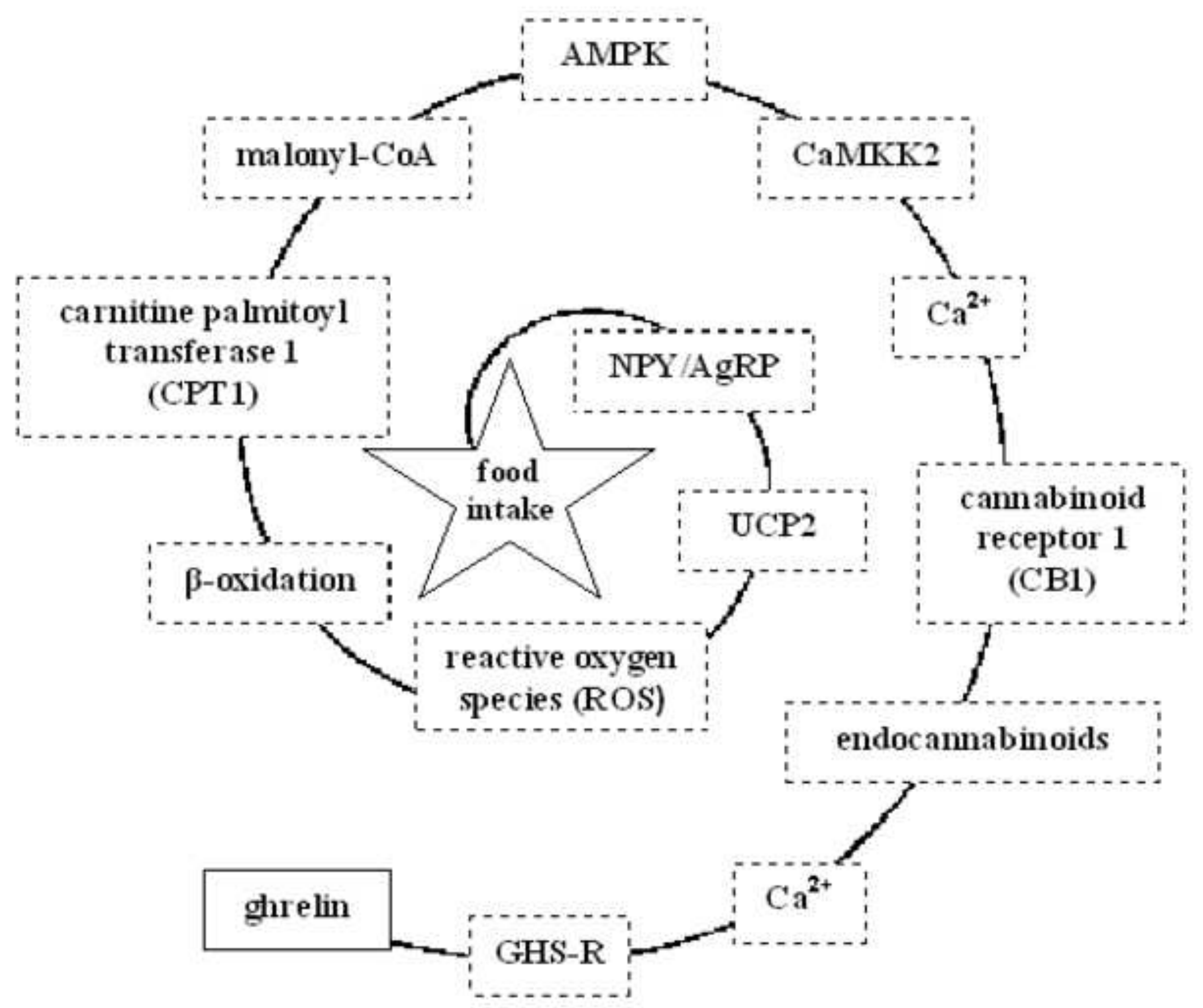


Figure 1: Flow diagram showing the proposed molecules involved in the appetiteinducing effect of ghrelin (Kola \& Korbonits, 2009). 


\section{GHRELIN}
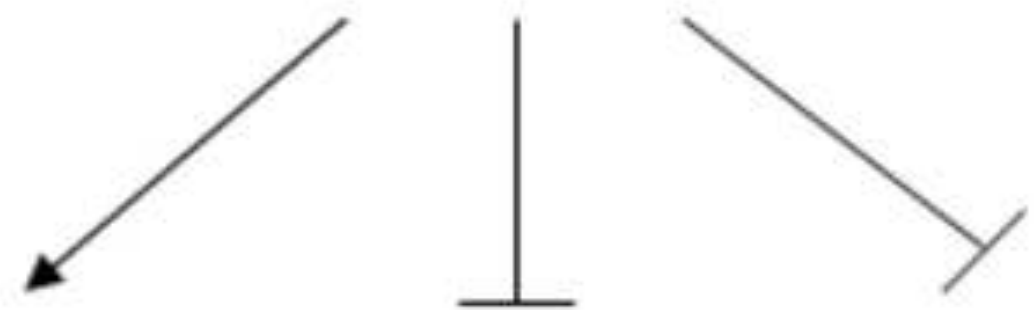

Hypothalamus AMPK

Liver AMPK

Adipose tissue AMPK
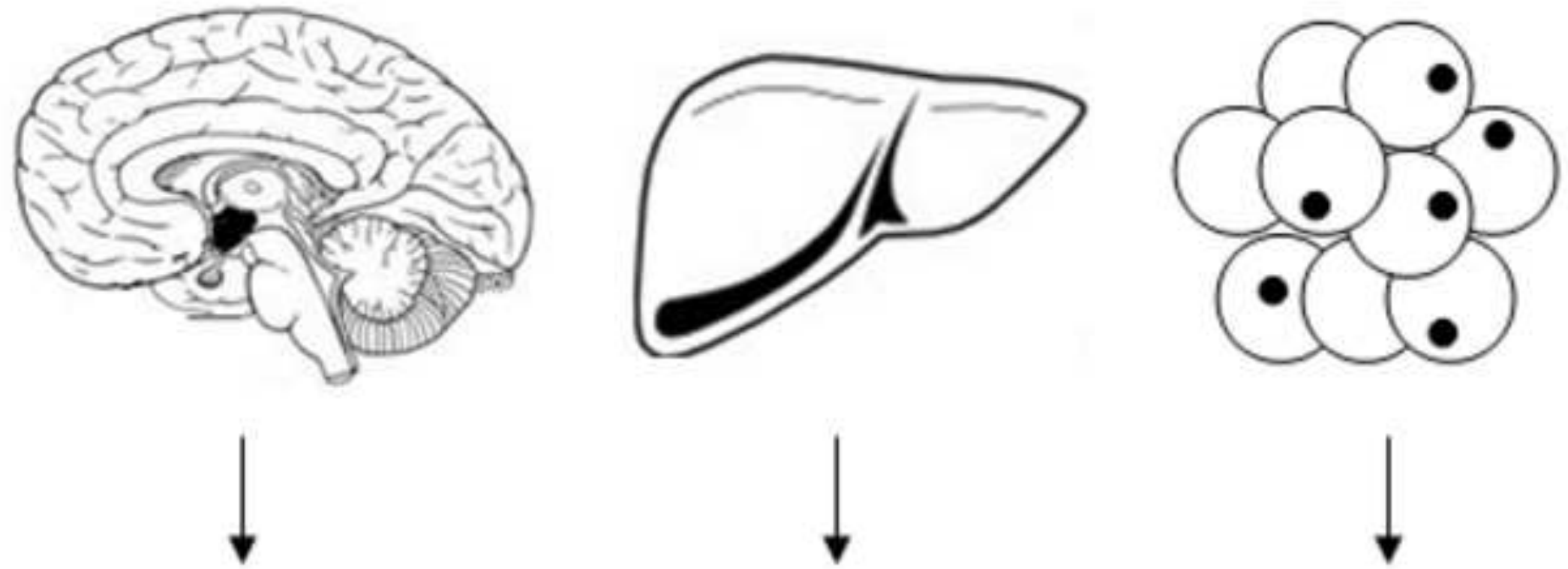

Appetite

Gluconeogenesis

Fatty acid and triglyceride synthesis 
Figure 2: Ghrelin has tissue-specific effects on AMPK activity. $\rightarrow$, stimulation; $\dashv$, inhibition (Kola et al., 2005; Kola et al., 2006). 